\title{
Bcl-xL Is Essential for the Survival and Function of Differentiated Neurons in the Cortex That Control Complex Behaviors
}

\author{
Ayumi Nakamura, ${ }^{1,2}$ Vijay Swahari, ${ }^{1}$ Charlotte Plestant, ${ }^{1}$ Ikuko Smith, ${ }^{1,3}$ Eric McCoy, ${ }^{1}$ Spencer Smith, $, 1,6$ \\ Sheryl S. Moy, ${ }^{4,5}$ E. S. Anton, ${ }^{1,4,6}$ and Mohanish Deshmukh ${ }^{1,2,4,6}$ \\ ${ }^{1}$ Neuroscience Center, ${ }^{2}$ Neurobiology Curriculum, ${ }^{3}$ Department of Pharmacology, ${ }^{4}$ Carolina Institute for Developmental Disabilities, ${ }^{5}$ Department of \\ Psychiatry, and ${ }^{6}$ Department of Cell Biology and Physiology, University of North Carolina, Chapel Hill, North Carolina 27599
}

\begin{abstract}
Apoptosis plays an essential role during brain development, yet the precise mechanism by which this pathway is regulated in the brain remains unknown. In particular, mammalian cells are known to express multiple anti-apoptotic Bcl-2 family proteins. However, the cells of the developing brain could also exist in a primed state in which the loss of a single anti-apoptotic Bcl-2 family protein is sufficient to trigger apoptosis. Here, we examined the critical role of $\mathrm{Bcl}-\mathrm{xL}$, an anti-apoptotic protein, during brain development. Using conditional knock-out mice in which Bcl-xL is deleted in neural progenitor cells $\left(B c l-x L^{E m x 1-C r e}\right)$, we show that the loss of Bcl-xL is not sufficient to trigger apoptosis in these proliferating progenitors. In contrast, specific populations of postmitotic neurons derived from these progenitors, including upper layer cortical neurons and the CA1-CA3 regions of the hippocampus, were acutely dependent on Bcl-xL. Consistent with this finding, deletion of Bcl-xL selectively in the postmitotic neurons in the brain $\left(B c l-x L^{N e x-C r e}\right)$ also resulted in similar patterns of apoptosis. This Bcl-xL deficiency-induced neuronal death was a consequence of activation of the apoptotic pathway, because the cell death was rescued with codeletion of the proapoptotic proteins Bax and Bak. Importantly, the loss of these Bcl-xL-dependent neurons led to severe neurobehavioral abnormalities, including deficits in motor learning, hyperactivity, and increased risk-taking and self-injurious behaviors. Together, our results identify a population of neurons in the developing brain that are acutely dependent on Bcl-xL during the peak period of synaptic connectivity that are important for the establishment of higher-order complex behaviors.
\end{abstract}

Key words: apoptosis; Bcl-xL; neurons; neural progenitor cells

Significance Statement

Although Bcl-xL is known to inhibit apoptosis, exactly which cells in the brain are dependent on Bcl-xL has remained unclear because of the embryonic lethality of mice globally deleted for Bcl-xL. Here, we conditionally deleted Bcl-xL in the brain and found that this did not result in widespread apoptosis in the proliferating progenitors. Instead, Bcl-xL deficiency induced apoptosis in a select population of differentiated neurons predominantly in the early postnatal stages. Importantly, these Bcl-xL-dependent neurons are not essential for survival of the organism but instead regulate complex behaviors. Our results show that the selective loss of these Bcl-xL-dependent neurons results in mice exhibiting severe neurobehavioral abnormalities, including self-injurious and risk-taking behaviors, hyperactivity, and learning and memory defects.

\section{Introduction}

Regulation of apoptosis is critical for proper embryonic and early postnatal brain development (Raff et al., 1993). The apoptotic pathway in the peripheral nervous system (PNS) is well known to be regulated by target-derived trophic factors that maintain the survival of neurons that are properly innervated at their distal

The authors declare no conflicts of interest. 
targets (Oppenheim 1991). In contrast, although neurons in the CNS are known to undergo apoptosis during development (Kuida et al., 1996; Cecconi et al., 1998; Hakem et al., 1998; Yoshida et al., 1998), exactly how apoptosis is regulated in the developing CNS remains unclear. For example, in contrast to PNS neurons, neurons in the developing CNS do not rely on a single trophic factor for their survival (Dekkers et al., 2013). However, increasing evidence indicates that CNS neurons rely more on neuronal activity and proper wiring of synaptic connections to maintain their survival (Dekkers and Barde 2013).

The key regulators of apoptosis are the Bcl-2 family proteins, which contain multiple proapoptotic (e.g., Bax, Bak) and antiapoptotic (e.g., Bcl-2, Bcl-xL, Mcl-1, Bcl-w) proteins (Youle and Strasser 2008; Chipuk et al., 2010). Although these proapoptotic or anti-apoptotic proteins are generally thought to have redundant functions, the emerging data points to a level of functional specificity for individual proteins that had not been appreciated previously. For example, deletion of Bax alone is sufficient to inhibit apoptosis in postmitotic neurons (Deckwerth et al., 1996; Besirli et al., 2003). In addition, although loss of Mcl-1 results in peri-implantation embryonic lethality (Rinkenberger et al., 2000), Bcl- $x L^{-/-}$global knockouts survive longer but are still embryonic lethal, with most knock-outs dying at embryonic day 13.5 (E13.5; Motoyama et al., 1995). The cause of death in Bcl-xL-deficient mice is postulated to be the extensive cell death that occurs in the liver hematopoietic cells, subsequently leading to anemia in these animals; however, another major organ system affected by loss of Bcl-xL is the brain (Motoyama et al., 1995; Roth et al., 1996).

$\mathrm{Bcl}-\mathrm{xL}$ is known to be expressed in both the embryonic and adult brain (Gonzalez-Garcia et al., 1994, 1995). Telencephalic neurons deficient in Bcl-xL are more sensitive to apoptosis both in vivo and in vitro (Motoyama et al., 1995; Roth et al., 1996). Moreover, in recent years, there has been increasing attention on the role of $\mathrm{Bcl}-\mathrm{xL}$ in regulating processes beyond neuronal apoptosis, including neurite outgrowth (Kretz et al., 2004; Park et al., 2015), synaptic plasticity (Jonas et al., 2003; Li et al., 2008, 2013), and mitochondrial bioenergetics (Vander Heiden et al., 2001; Chen et al., 2011). Although there has been focus on both the apoptotic and non-apoptotic roles of $\mathrm{Bcl}-\mathrm{xL}$ in the nervous system, a systematic examination of the consequence of $\mathrm{Bcl}-\mathrm{xL}$ deficiency in the brain has not been conducted to date.

Here, we generated conditional knock-out mice in which $\mathrm{Bcl}-\mathrm{xL}$ is specifically deleted in the neural progenitor cells (NPCs) of the telencephalon and in the postmitotic cells of the brain. We show that, although loss of Bcl-xL appears to be dispensable for the survival of NPCs, specific populations of postmitotic neurons in the brain critically rely on Bcl-xL for their survival and function. The brains of Bcl-xL-deficient mice displayed severe microcephaly as a result of increased apoptotic cell death in the neurons of the cortex and hippocampus during the early postnatal stages, a phenomenon that is rescued with deletion of Bax and Bak. In vivo imaging for visually evoked neural activity in mice deleted for Bcl-xL revealed an abnormally small retinotopic map in the visual cortex that surprisingly remained topographically intact and functional. Importantly, Bcl-xL deficiency led to severe consequences in the animal, including deficits in motor learning, self-injurious behavior, overt hyperactivity, and increased risk-

Correspondence should be addressed to Mohanish Deshmukh, University of North Carolina, Department of Cell Biology and Physiology, 7109E Neuroscience Research Building, Chapel Hill, NC 27599. E-mail: mohanish@med.unc.edu.

DOI:10.1523/JNEUROSCI.4247-15.2016

Copyright (C) 2016 the authors $\quad 0270-6474 / 16 / 365449-14 \$ 15.00 / 0$ taking behavior. Together, these results point to the critical role of Bcl-xL in the survival of specific postmitotic neurons in the developing mammalian brain, the loss of which results in neurobehavioral deficits.

\section{Materials and Methods}

Mice

$B c l-x L^{\operatorname{loxP} / l o x P}$ mice were generously provided by Dr. You-Wen He (Duke University, Durham, NC). To induce conditional deletion of Bcl-xL, $B c l-x L^{\operatorname{loxP} / l o x P}$ mice were crossed with two different Cre lines, Emx1-Cre and Nex-Cre. Emx1-Cre and tdTomato mice were a kind gift from Dr. William Snider [University of North Carolina (UNC), Chapel Hill, NC] and Dr. Timothy Gershon, respectively (UNC-Chapel Hill). All other mice were obtained from The Jackson Laboratory. Mice were maintained in a $12 \mathrm{~h}$ light/dark cycle (lights on at 7:00 A.M., lights off at 7:00 P.M.). All animal handling and protocols were performed in accordance with established practices as described in the National Institutes of Health Guide for the Care and Use of Laboratory Animals and as approved by the Institutional Animal Care and Use Committee at UNC-Chapel Hill.

\section{Surgeries}

For intrinsic signal optical imaging, a craniotomy was performed on a total of six mice aged P29-P34 $(n=3$ wild-type mice, $n=3$ $B c l-x L^{E m x l-C r e}$ mice). Mice were anesthetized with isoflurane (5\% for induction, $1-2 \%$ for surgery, $0.5 \%$ for imaging) augmented with chlorprothixene $(2.5 \mathrm{mg} / \mathrm{kg}$, i.p.). The skull overlaying the right visual cortex was exposed, and a custom head-fixing imaging chamber with a 5-mm-diameter opening was mounted and secured with cyanoacrylate glue (Oasis Medical) and dental acrylic (Lang Dental). A 4-mm-diameter craniotomy was made within the chamber to expose the visual cortex for imaging. The imaging chamber was then filled with a saline solution containing the following (in $\mathrm{mM}$ ): 150 $\mathrm{NaCl}, 2.5 \mathrm{KCl}, 10 \mathrm{HEPES}, 2 \mathrm{CaCl}_{2}$, and $1 \mathrm{MgCl}_{2}$. Physically activated heat packs (SpaceGel; Braintree Scientific) and a feedback-controlled electric heat pad system (custom-built; $37^{\circ} \mathrm{C}$ ) were used for maintaining body temperature during surgery and imaging, respectively.

\section{Intrinsic signal optical imaging}

Custom instrumentation adapted from previous reports (Kalatsky and Stryker 2003; Smith and Trachtenberg, 2007) was used. Briefly, two F-mount lenses were used to form a tandem lens macroscope (respective focal lengths of 135 and $50 \mathrm{~mm}$; Nikon) that was connected to a DALSA 1M30 CCD camera (Teledyne DALSA), providing a $4.6 \times 4.6 \mathrm{~mm}$ field of view. The pial vasculature illuminated (Asahi Spectra low-noise halogen source) with green light (550 $\pm 50 \mathrm{~nm}$; Edmund Optics) and imaged through a green emission filter $(560 \pm 5 \mathrm{~nm})$ served as a landmark for depth. From the vasculature, the imaging was focused $600 \mu \mathrm{m}$ deep into the neocortex in which hemodynamic intrinsic signals were imaged with red light $(700 \pm 38 \mathrm{~nm}$; Chroma Technology). Reflected light was then captured through a second red filter (700 $\pm 5 \mathrm{~nm}$; Edmund Optics) at 30 frames/s with custom image acquisition software (code kindly provided by D. Ferster, Northwestern University, Evanston, IL; with adaptations by J. Stirman, UNC-Chapel Hill). Fourier analysis was performed on each pixel column to measure the magnitude and phase of stimulus-evoked signals at the frequency of the periodic visual stimuli $(0.125 \mathrm{~Hz})$. Area and vertical and horizontal diameters of the entire primary visual cortex $(\mathrm{V} 1)$ and a portion of the $\mathrm{V} 1$ representing $50^{\circ}$ visual space were measured using NIH ImageJ software (Schindelin et al., 2012).

\section{Visual stimuli}

Head-fixed mice were positioned $20 \mathrm{~cm}$ from an LCD monitor $(60 \times$ $34 \mathrm{~cm}$ ) that was tilted $17.5^{\circ}$ from vertical toward the mouse. The nose of the animal was pointed to the right edge of the monitor such that the stimulus covered $110^{\circ} \times 75^{\circ}$ of visual space and was viewed by the contralateral eye. A $3^{\circ}$ thick drifting white bar sweeping across the monitor once every $8 \mathrm{~s}$ on a black background (horizontal or vertical) was used for retinotopic mapping, and a vertical grating patch $\left(50^{\circ}\right.$ diameter displayed at the center of the monitor, 2 cycles/s, $0.04 \mathrm{cy}-$ $\mathrm{cle}^{\circ}$ ) drifting for the last $2 \mathrm{~s}$ of an $8 \mathrm{~s}$ period was used to measure basic cortical representation of a $50^{\circ}$ visual space. The periodic motion cycle for both of these stimuli was at $0.125 \mathrm{~Hz}$ and repeated 50 cycles. 
The stimulus movies were produced and presented using MATLAB (Pelli 1997) and the Psychophysics Toolbox (Brainard 1997) and were corrected for three-dimensional distortion because of the flatness of the monitor using a custom MATLAB code (code is available online; http://labrigger.com/blog/2012/03/06/mouse-visual-stim/).

\section{Behavioral regimen}

Subjects were $16 \mathrm{Bcl}-x L^{\mathrm{Nex}-\mathrm{Cre}}$ (10 males and 6 females) and 19 wild-type controls ( 10 males and 9 females). Testing began when mice were $\sim 6-7$ weeks of age. For each procedure, measures were taken by an observer blind to mouse genotype. Mice were tested in the following assays, with one or two tests per week: elevated plus maze, open field, rotarod, and Morris water maze.

Elevated plus maze. This test was used to assess anxiety-like behavior, based on a natural tendency of mice to actively explore a new environment versus a fear of being in an open area. Mice were given one 5-min trial on the plus maze, which had two walled arms (the closed arms, $20 \mathrm{~cm}$ in height) and two open arms. The maze was elevated $50 \mathrm{~cm}$ from the floor, and the arms were $30 \mathrm{~cm}$ long. Mice were placed on the center section $(8 \times 8 \mathrm{~cm})$ and allowed to freely explore the maze. Measures were taken of percentage time spent in the open arms and percentage entries into the open arms. The total number of entries was used as an index for activity during the test.

Open-field test. Exploratory activity in a novel environment was assessed by a $60 \mathrm{~min}$ trial in an open-field chamber $(41 \times 41 \times 30 \mathrm{~cm})$ crossed by a grid of photobeams (VersaMax system; AccuScan Instruments). Counts were taken of the number of photobeams broken during the trial in $5 \mathrm{~min}$ intervals, with measures for total distance traveled, rearing movements, and time spent in the center region.

Rotarod. Subjects were tested for motor coordination and learning on an accelerating rotarod (Ugo Basile, Stoelting). For the first test session, animals were given three trials, with $45 \mathrm{~s}$ between each trial. Two additional trials were given $48 \mathrm{~h}$ later. Revolutions per minute was set at an initial value of 3 , with a progressive increase to a maximum of $30 \mathrm{rpm}$ across 5 min (the maximum trial length). Measures were taken for latency to fall from the top of the rotating barrel.

Morris water maze. The visible platform task was used to assess swimming ability and visual function. The water maze consisted of a large circular pool (122 cm diameter) partially filled with water (45 cm deep, $24-26^{\circ} \mathrm{C}$ ), located in a room with numerous visual cues. Each mouse was given four trials per day, across $3 \mathrm{~d}$, to swim to an escape platform cued by a patterned cylinder extending above the surface of the water. For each trial, the mouse was placed in the pool at one of four possible locations (randomly ordered) and then given $60 \mathrm{~s}$ to find the visible platform. If the mouse found the platform, the trial ended, and the animal was allowed to remain $10 \mathrm{~s}$ on the platform before the next trial began. If the platform was not found, the mouse was placed on the platform for $10 \mathrm{~s}$ and then given the next trial. Measures were taken of latency to find the platform, swimming speed, and swimming distance via an automated tracking system (EthoVision; Noldus).

Hargreaves assay. Heat sensitivity was measured by heating each hindpaw once per day using the Plantar Test apparatus (IITC) with a cutoff time of $20 \mathrm{~s}$. Ten $B c l-x L^{\text {Nex-Cre }}$ ( 5 males and 5 females) and 10 wild-type controls ( 5 males and 5 females) were tested in this assay.

\section{Immunohistochemistry}

For immunohistochemistry (IHC) experiments, mice were anesthetized using isoflurane and transcardially perfused with $4 \%$ paraformaldehyde. The mice were then decapitated, and the brains were postfixed in $4 \%$ paraformaldehyde overnight. All of the stained sections were obtained from identical regions of the brain that were carefully selected based on structural and anatomical landmarks. Paraffin-embedded sections were used for hematoxylin-eosin, cleaved caspase-3 (catalog \#CP229C, Biocare Medical), NeuN (catalog \#MAB377, Millipore), Bcl-xL (catalog \#2764, Cell Signaling Technology), proliferating nuclear antigen (catalog \#2586, Cell Signaling Technology), RFP (catalog \#600-401-379, Rockland Immunochemicals), Bax (catalog \#AF820, R\&D Systems), and Bak (catalog\#12105, Cell Signaling Technology). Briefly, IHC was performed in the Bond Autostainer (Leica). Slides were dewaxed in Bond Dewax solution (part \#AR9222; Leica) and hydrated in Bond Wash solution (catalog \#AR9590; Leica). Antigen retrieval was performed for $30 \mathrm{~min}$ at $100^{\circ} \mathrm{C}$ in Bond-Epitope Retrieval solution 1 pH 6.0 (catalog \#AR9961; Leica). Slides were incubated with the primary antibodies for $1 \mathrm{~h}$. DAPI or hematoxylin was used as a nuclear stain. Antibody detection was performed using the Bond Polymer Refine Detection System (catalog \#DS9800; Leica). Stained slides were dehydrated and coverslipped. Representative images are obtained from independent experiments, done at least in triplicate.

For all other stains, wild-type and Bcl-xL-deficient brains were embedded in $4 \%$ low-melting-point agarose in $1 \times$ PBS and were sectioned coronally $(50 \mu \mathrm{m})$ on a vibratome (VT 1200S; Leica). The following antibodies were used for IHC on vibratome sections: cleaved caspase-3 (catalog \#9664; Cell Signaling Technology), Cux1 (catalog \#sc-13024; Santa Cruz Biotechnology), Brn1 (kind gift from A. Ryan, McGill University, Montreal, Quebec, Canada), Tbr1 (catalog \#ab31940; Abcam), and NeuN (catalog \#MAB377; Millipore). Appropriate anti-mouse, antirabbit, anti-rat, or anti-guinea pig secondary antibodies were used to detect primary antibody binding. DAPI was used as a nuclear stain. Representative images are obtained from independent experiments, done at least in triplicate.

\section{Statistics}

Statistical analyses were performed using GraphPad Prism 5 or Statview 5.0.1 (SAS) software. Ex vivo data are obtained from at least three independent experiments and expressed as mean \pm SEM unless otherwise specified. The Student's $t$ test (unpaired, two-tailed) for parametric data was used for analysis of two groups. Behavioral data were analyzed using one-way, two-way, or repeated-measures ANOVAs, with the factors genotype and sex. Fisher's protected least-significant difference tests were used for comparing group means only when a significant $F$ value was determined. No statistical methods were used to predetermine sample sizes, but our sample sizes are consistent with those reported in previous publications.

\section{Results}

\section{Bcl-xL deletion leads to cell death of newly differentiated neurons}

Mice globally deleted for Bcl-xL are embryonic lethal at E13.5 (Motoyama et al., 1995). Although Bcl-xL is known to regulate apoptosis in neurons, its essential role in the survival of hematopoietic cells precluded studies that could identify the precise function of Bcl-xL in the nervous system. To critically examine the role of $\mathrm{Bcl}-\mathrm{xL}$ in the developing brain, we generated conditional knock-outs by crossing mice floxed for Bcl-xL with Emx1Cre mice $\left(B c l-x L^{\operatorname{lox} P / l o x P} ; E m x 1-C r e\right.$, hereafter referred to as $\left.B c l-x L^{E m x l-C r e}\right)$. To confirm that Emxl-Cre induces recombination in the NPCs of the dorsal telencephalon (Gorski et al., 2002), we also generated Emx1-Cre;rosa26reporter-tdTomato mice. As expected, there is robust expression of tdTomato in the dorsal telencephalon at E12.5 (Fig. 1A). Our results show that $\mathrm{Bcl}-\mathrm{xL}$ expression is lost throughout all layers of the cortex in the $B c l-x L^{E m x l-C r e}$ mice (Fig. $1 B$ ). A few neurons, including some excitatory projection neurons and interneurons, continue to exhibit Bcl-xL immunoreactivity, because Emx1-Cre is known to induce recombination at an efficiency of $\sim 88 \%$ in the cortex and does not induce recombination in interneurons (Gorski et al., 2002; Fig. 1B).

In contrast to mice globally deleted for Bcl-xL, $B c l-x L^{E m x l-C r e}$ mice were born at the expected Mendelian ratio and appeared normal at postnatal day 1 (P1; Fig. $1 C$ ). At P1, the brains of $B c l-x L^{\text {Emxl-Cre }}$ mice also appeared similar to those of wild-type mice, and there was no difference in the brain weights between the two genotypes (Fig. $1 D, E$ ). However, by P25, although $B c l-x L^{\text {Emxl-Cre }}$ mice remained grossly normal, examination of their brains revealed profound microcephaly (Fig. $1 F-H$ ). From $\mathrm{P} 1$ to $\mathrm{P} 30, \mathrm{Bcl}-x L^{\text {Emxl-Cre }}$ mice also exhibited a significant reduction in the cortical thickness, and the number of NeuN-positive 
A

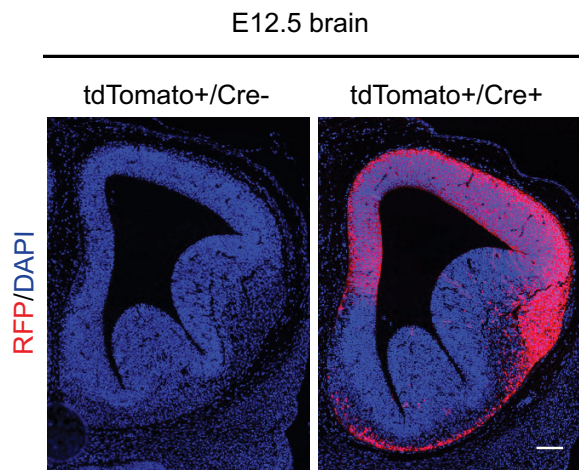

B

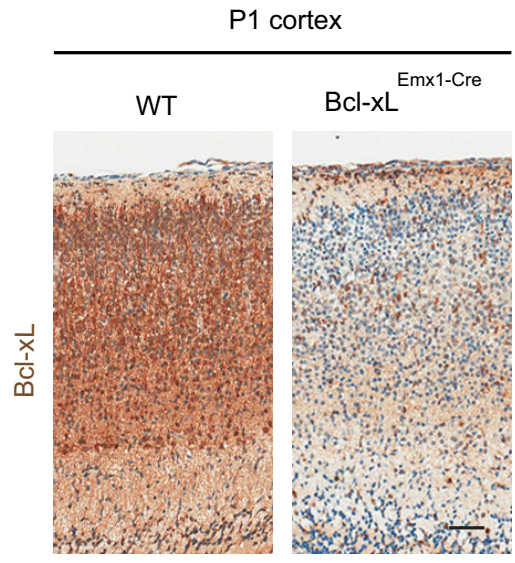

C

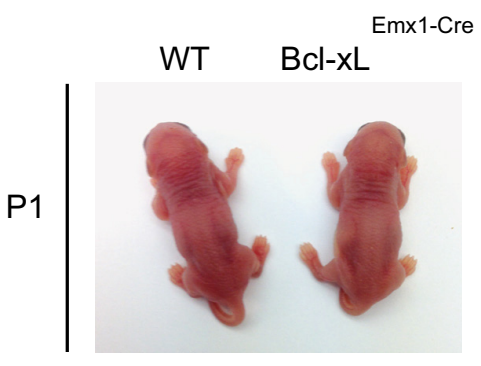

F

WT

Bcl-xL

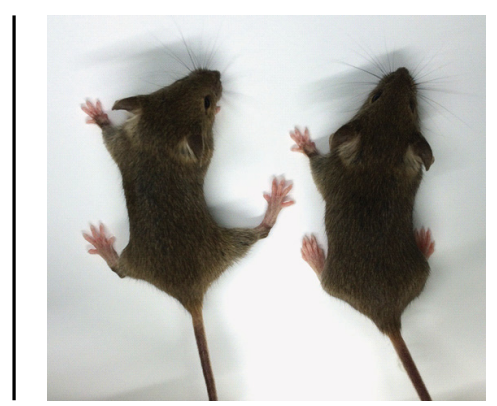

D

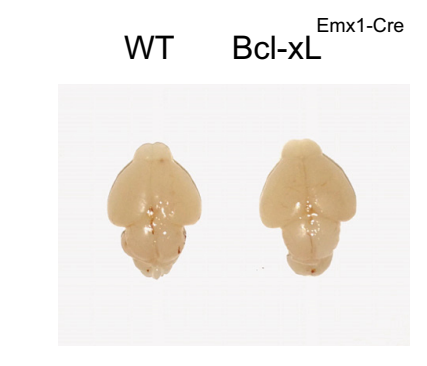

G
E

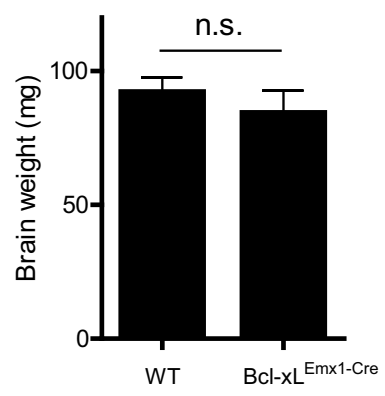

H

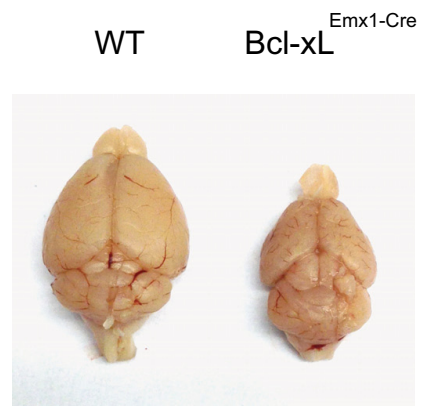

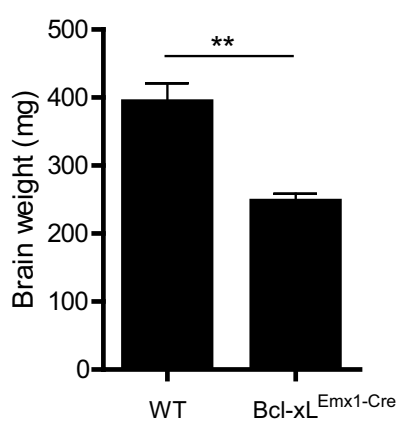

Figure 1. Loss of $\mathrm{BCl}-\mathrm{xL}$ in the dorsal telencephalon results in microcephaly. $A$, tdTomato ${ }^{+} / \mathrm{Cre}^{-}$(rosa26reporter-tdTomato; no Cre control) and tdTomato ${ }^{+} / \mathrm{Cre}^{+}$(Emx1-Cre; rosa26reporter-tdTomato) brains at E12.5 stained with RFP show the recombination pattern of the Emx1-Cre line. Scale bar, $100 \mu \mathrm{m}$. B, Wild-type and BCl-xL ${ }^{\text {Emx } 1-C r e}$ mouse cortices stained with BCl-xL at P1. Samples were counterstained with hematoxylin. Scale bar, $50 \mu \mathrm{m}$. C, Wild-type and $B C l-x L^{E m x 1-C r e}$ mice at P1. Images of brains $(\boldsymbol{D})$ and brain weights of P1 wild-type and $B C l-x L^{E m x 1-C r e}$ mice $(\boldsymbol{E})$. $\boldsymbol{F}$, Wild-type and $B C-x L^{E m x 1-C r e}$ mice at P25. Images of brains $(\boldsymbol{G})$ and brain weights of P25 wild-type and $B C-$-xL ${ }^{\text {Emx1-Cre }}$ mice $(\boldsymbol{H})$. Data shown are means \pm SEM for each group. ** $p<0.01$; n.s., not significant.

cells throughout the cortex at P30 was markedly reduced in the $B c l-x L^{\text {Emxl-Cre }}$ mice (Fig. $2 A-G$ ).

The fact that the deletion of $\mathrm{Bcl}-\mathrm{xL}$ in the developing brain did not result in embryonic lethality prompted us to examine $\mathrm{Bcl}-\mathrm{xL}$ expression in the developing brain. Contrary to our expectation that $\mathrm{Bcl}-\mathrm{xL}$ is expressed throughout the brain, we found that the expression of Bcl-xL was significantly higher in the nonproliferating cells of the cortex compared with the proliferating progenitors in the subventricular zone (Fig. $3 A-C$ ). To determine whether the microcephaly observed in $B c l-x L^{E m x l-C r e}$ mice postnatally was attributable to increased apoptosis, we probed the brains for cleaved caspase- 3 at multiple time points (E16, P1). Consistent with the expression patterns of $\mathrm{Bcl}-\mathrm{xL}$ throughout the brain, cell death in the Bcl-xL-deficient embryonic brain occurred primarily in the NeuN-positive differentiated neurons, whereas the proliferating (PCNA-positive) progenitors were mostly spared (Fig. 3D-H). Even more striking, we found that deletion of $\mathrm{Bcl}-\mathrm{xL}$ induces cell death and formation of pyknotic nuclei predominantly at P1 in the cortex of the postnatal brain (Fig. $4 A-D$ ). Analysis of the hippocampus also showed extensive cell death in the CA1-CA3 regions of $B c l-x L^{E m x l-C r e}$ mice at P1 (Fig. $4 E, F$ ). Thus, consistent with its pattern of expression, deletion of Bcl-xL selectively affects the postmitotic neurons rather than their proliferating progenitors.

\section{Bcl-xL deficiency induces cell death predominantly in upper} layer cortical neurons and results in a significantly smaller but functional visual cortex

Because the majority of cells that are undergoing apoptosis in $B c l-x L^{E m x 1-C r e}$ mice at $\mathrm{P} 1$ are located in the upper regions of the cortex, we investigated the specific neuronal layers that are affected most by Bcl-xL deficiency. By P30, the Bcl- $x L^{\text {Emxl-Cre }}$ mice 
A P1

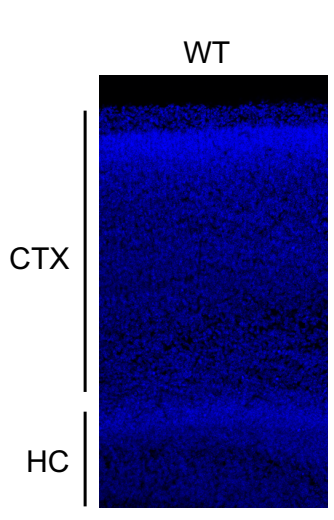
$\mathrm{Bcl}-\mathrm{xL}$

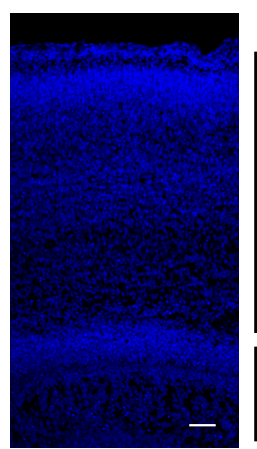

C
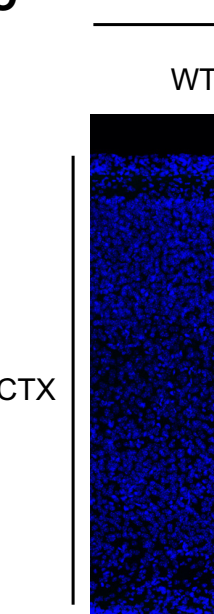

P7

WT

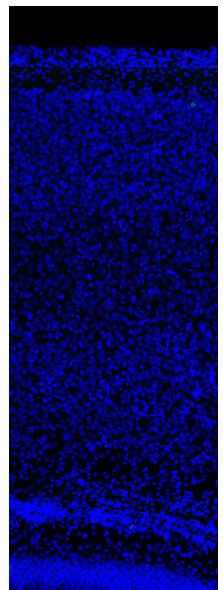

$\mathbf{E}$ P30

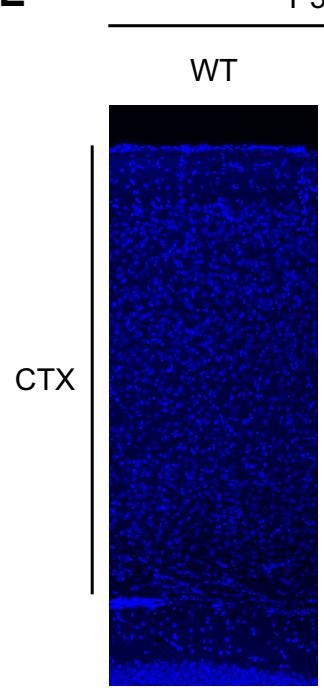
Bcl-xL

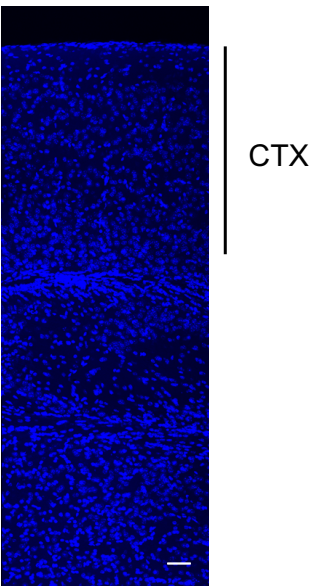

B
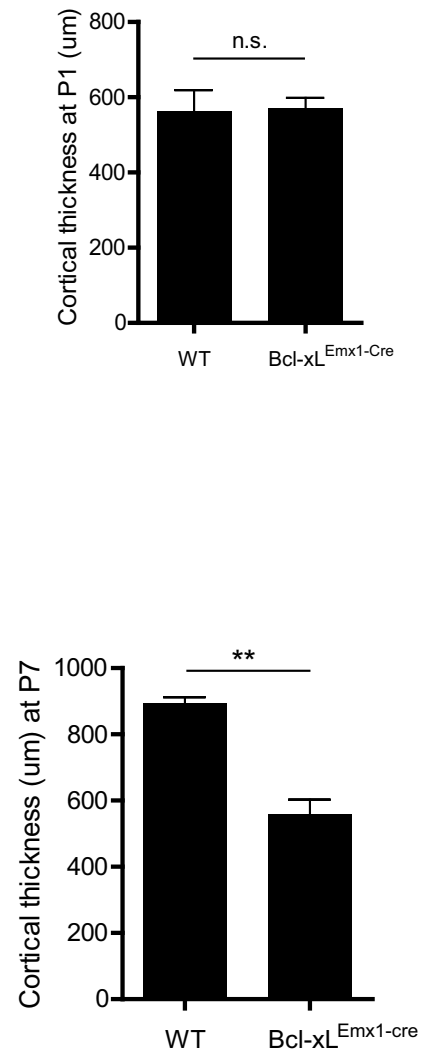

G

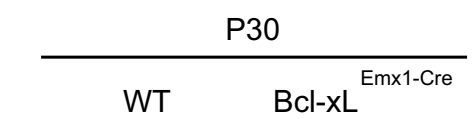

$\mathbf{F}$

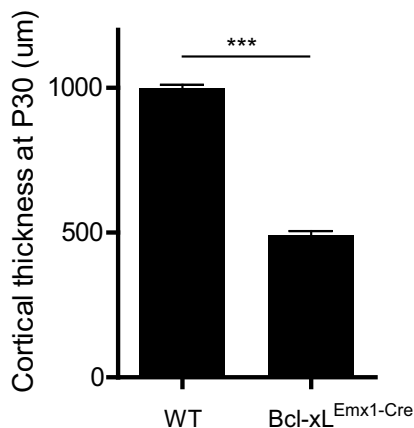

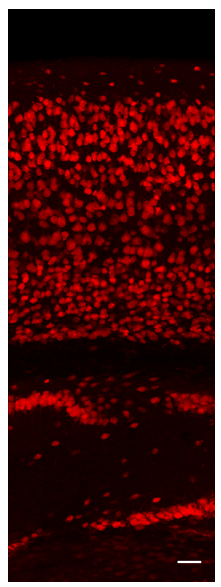

Figure 2. $B C l-x L$ deletion in the brain causes a reduction in cortical thickness by $P 30$. $A$, Wild-type and $B C l-x L^{E m x 1-C r e}$ mouse brains stained with DAPI at P1. Quantification of the cortical thickness is shown in $B$. C, Wild-type and $B C l-x L^{E m x 1-C r e}$ mouse brains stained with DAPI at P7. Quantification of the cortical thickness is shown in $\boldsymbol{D}$. $\boldsymbol{E}$, Wild-type and $B C l-x L^{E m \times 1-C r e}$ mouse brains stained with DAPI at P30. Quantification of the cortical thickness is shown in $\boldsymbol{F}$. G. Wild-type and BCl-xL ${ }^{\text {Emx }}{ }^{-C r e}$ mouse brains stained with NeuN (neuronal marker) at P30. CTX, Cortex; HC, hippocampus. Scale bars: $\boldsymbol{A}, \boldsymbol{C}, \boldsymbol{E}, \mathbf{G} 50 \mu \mathrm{m}$. Data shown are means \pm SEM for each group. ${ }^{* *} p<0.01 ;{ }^{* * *} p<0.0001$; n.S., not significant. 
A

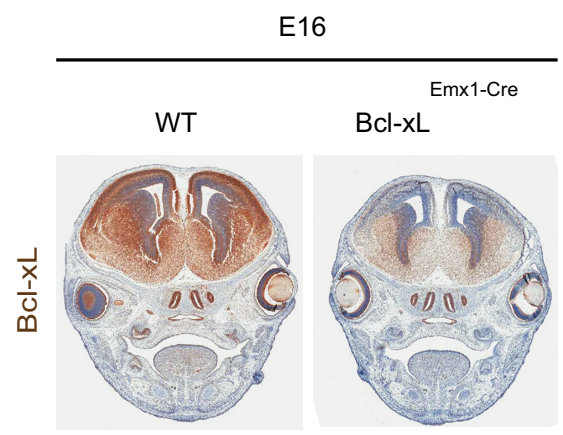

D
B

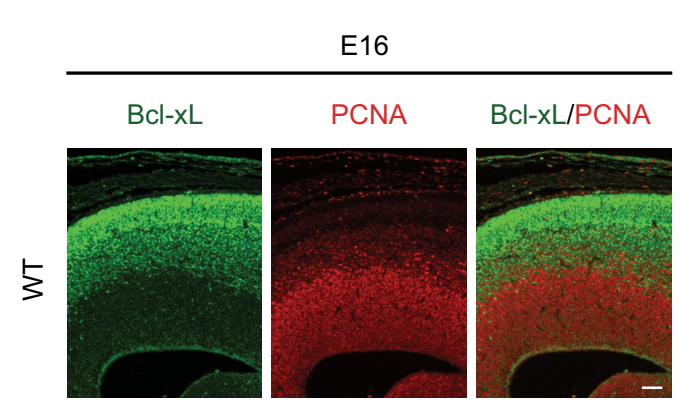

C

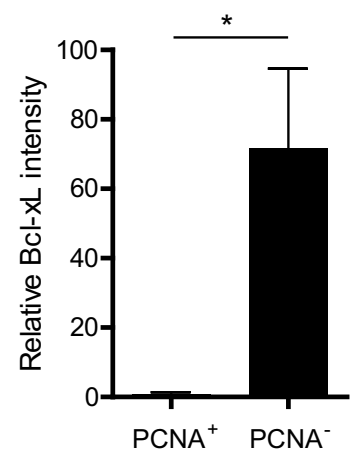

E16

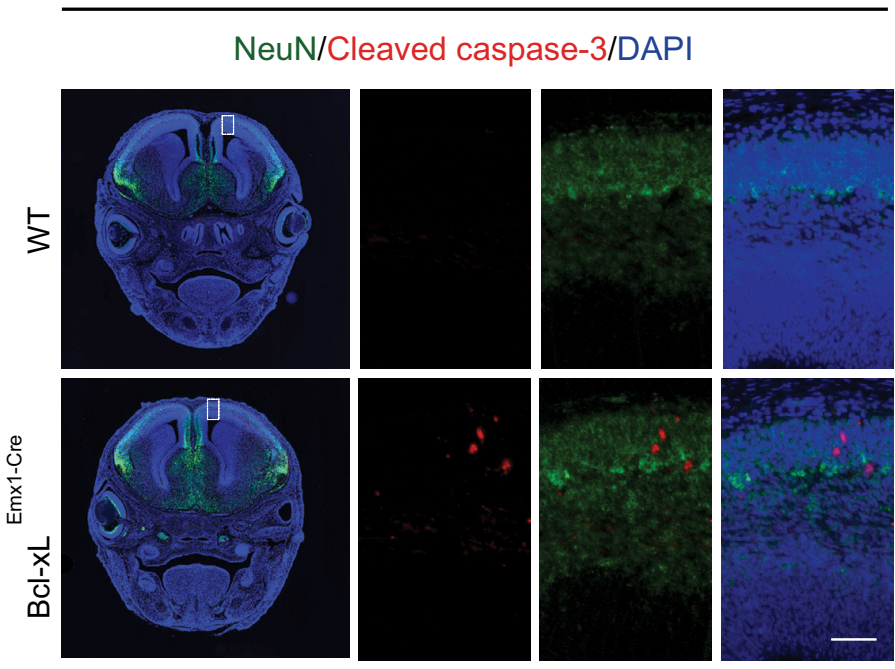

E

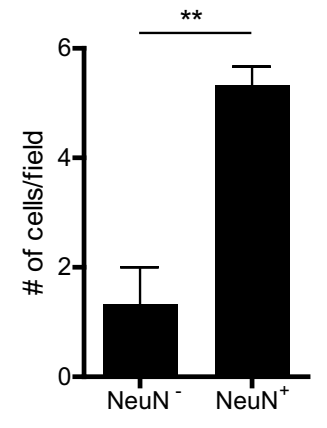

F

E16

G

H
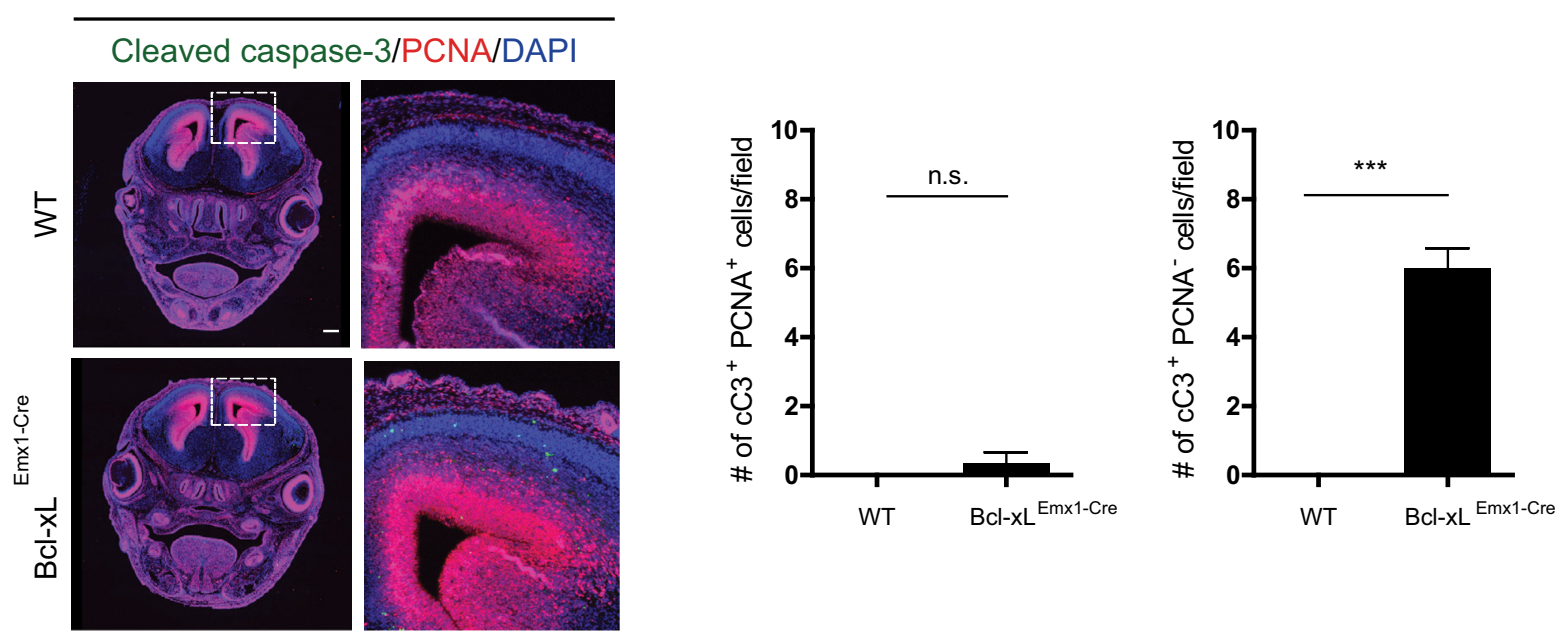

Figure 3. $B C l-x L$ deletion leads to cell death in postmitotic neurons. $A$, Brains of wild-type and $B C l-x L{ }^{E m \times 1-C r e}$ mice at E16 stained with BCl-xL. B, Cortex of wild-type mice at E16 stained with a marker of proliferation, PCNA (red), and BCl-xL (green). Scale bar, $50 \mu \mathrm{m}$. C, Quantification of BCl-xL in PCNA-positive and PCNA-negative cells shown in $\boldsymbol{B}$. D, Brains of wild-type and $B C l-x L^{E m \times 1-C r e}$ mice at E16 costained with NeuN (green), cleaved caspase-3 (red), and DAPI. E, Quantification of the number of cleaved caspase-3-positive cells in the NeuN-negative and NeuN-positive populations in the BCl-xL ${ }^{E m x 1-C r e}$ cortex. Scale bar, $25 \mu \mathrm{m}$. F, Cortices of wild-type and BCl-xL ${ }^{\text {Emx1-Cre }}$ mice at E16 stained with cleaved caspase-3, PCNA, and DAPI. The image on the right is a magnified image of the cortex (dotted white box). Scale bar, $300 \mu \mathrm{m}$. G, Quantification of the number of cleaved caspase-3-positive and PCNA-positive cells shown in $\boldsymbol{F}$. $\boldsymbol{H}$, Quantification of the number of cleaved caspase-3-positive and PCNA-negative cells shown in $\boldsymbol{F}$. Data shown are means \pm SEMs for each group. ${ }^{*} p<0.05$, ${ }^{* *} p<0.01$, ${ }^{* * *} p<0.001 ;$ n.s., not significant. 
A

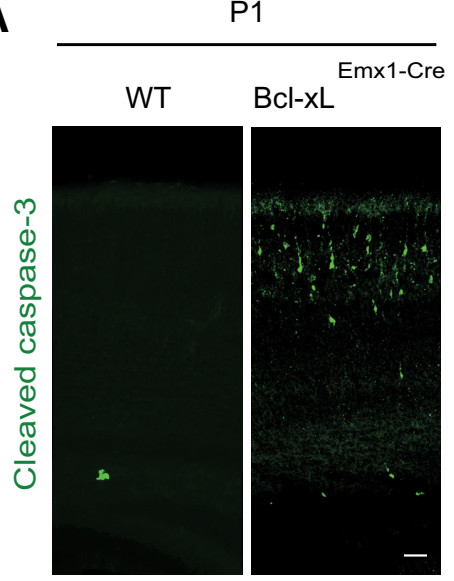

C

B

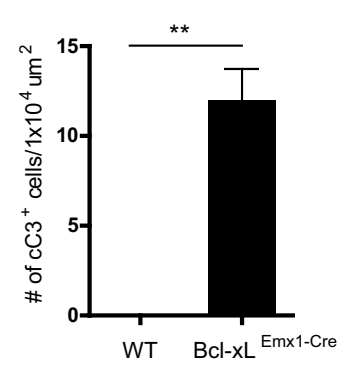

P1

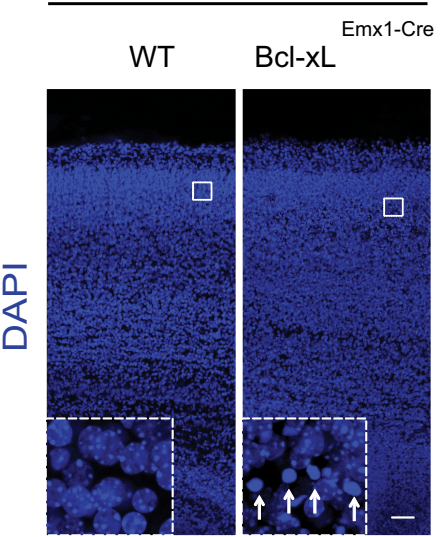

D

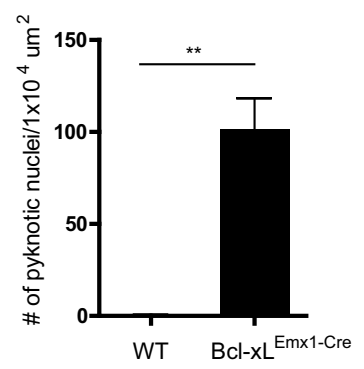

E

P1

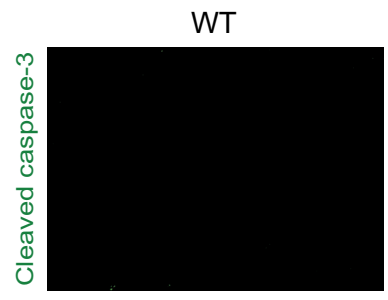

G

P30

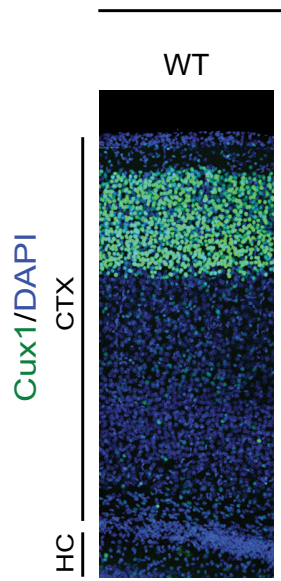

H

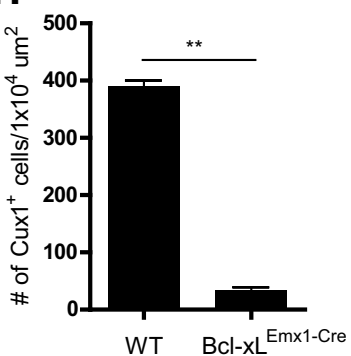

$\mathbf{F}$

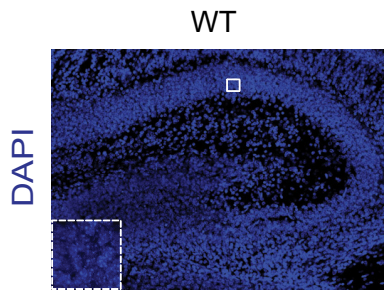

P1

Bcl-xL

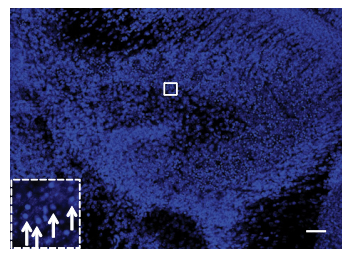

K

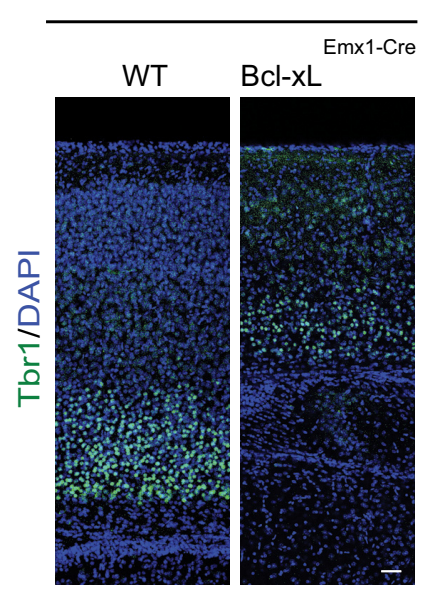

L

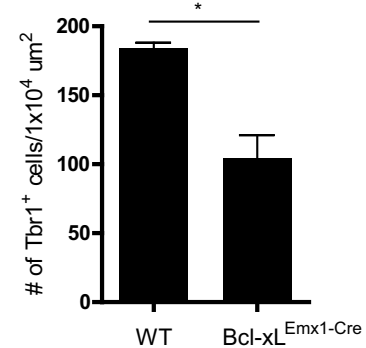

Figure 4. $B C l-x L$ is critical for the survival of specific populations of cortical neurons. $A$, Cortices of $\mathrm{P} 1$ wild-type and $B C l-x L{ }^{E m x 1-C r e}$ mice stained with cleaved caspase-3, a marker of apoptosis. $\boldsymbol{B}$, Quantification of the number of cleaved caspase-3-positive cells shown in $A$. C, Presence of pyknotic nuclei in the cortex of $B C l-x L^{E m x 1-C r e}$ mice. Inset, Magnified image of the white box in the cortex. White arrows denote pyknotic nuclei. $\boldsymbol{D}$, Quantification of the number of pyknotic nuclei shown in $\boldsymbol{C}$. $\boldsymbol{E}$, Hippocampus of P1 wild-type and $B C-$ - $x L^{E m \times 1-C r e}$ mice stained with cleaved caspase-3. $\boldsymbol{F}$, Hippocampus of P1 wild-type and BCI-xL ${ }^{\text {Emx } 1-C r e}$ mice stained with DAPI reveal the presence of pyknotic nuclei. Inset, Magnified image of the white box in the hippocampus. White arrows denote pyknotic nuclei. Cortices of P30 wild-type and BCl-xL Emx1-Cre mice costained with DAPI and Cux1 (G), Brn1 (I), and Tbr1 (K). Quantification of the number of Cux1-positive cells $(\boldsymbol{H})$, Brn1-positive cells $(\boldsymbol{J})$, and Tbr1-positive cells $(\boldsymbol{L})$. Data shown are means \pm SEMs for each group. CTX, Cortex; $H C$, hippocampus. The wild-type image in $\mathbf{G}$ shows the cortex and the top region of the hippocampus in the wild-type and $B C l-x L^{E m \times 1-C r e}$ mice. Scale bars: $A, C, E-G, I, K, 50 \mu \mathrm{m} .{ }^{*} p<0.05,{ }^{* *} p<0.01$. 
A

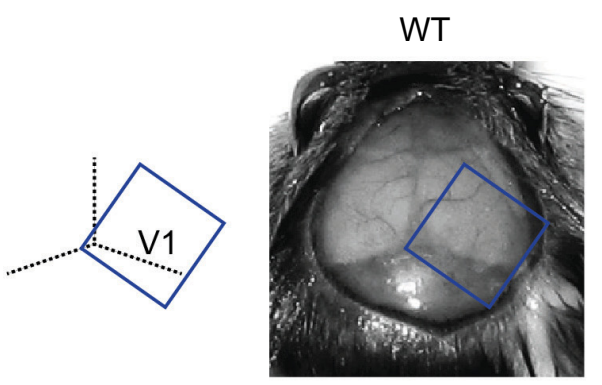

\author{
Emx1-Cre
}

Bcl-XL

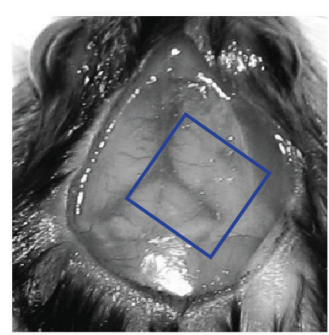

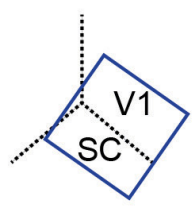

B

WT

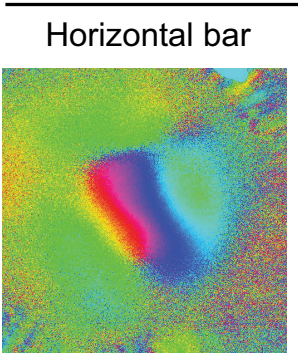

C

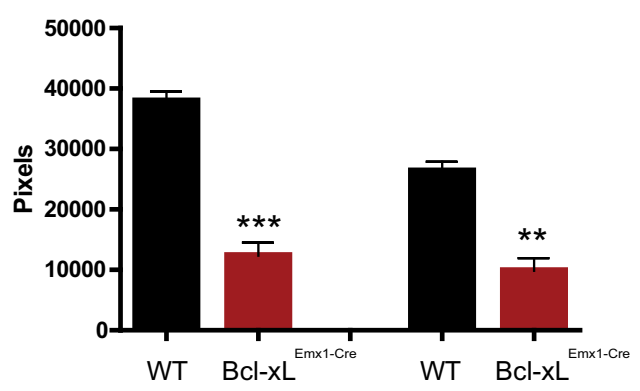

$\mathrm{Bcl}-\mathrm{xL}$ Emx1-Cre

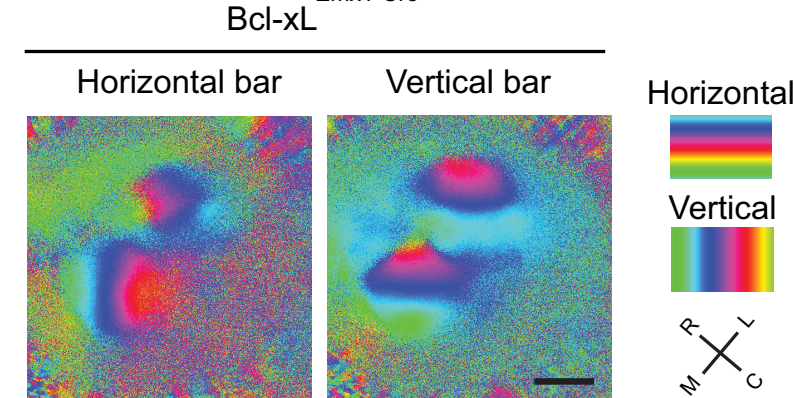

D 50-degrees (vertical) 50-degrees (horizontal)

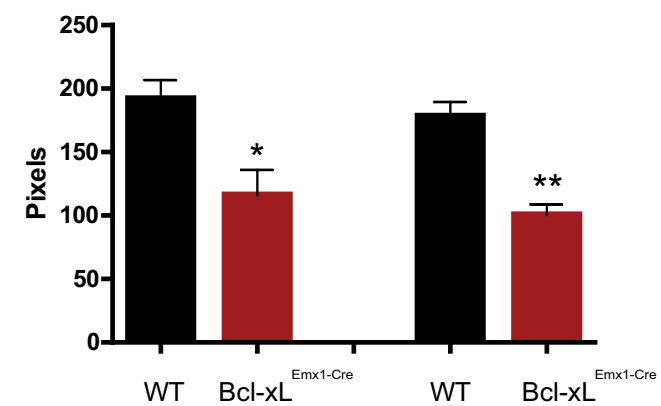

Figure 5. Loss of BCl-xL leads to a smaller but functional retinotopic map in the visual cortex. A, Microcephaly in $B C l-x L^{E m x 1-C r e}$ mice. Tilted rectangles depict the in vivo imaging field of view. SC, Superior colliculus. B, Retinotopic maps acquired with in vivo imaging of visually evoked responses to horizontal (left) and vertical (right) bars in wild-type and BCl-xL ${ }^{E m \times 1-C r e}$ mice. C, Caudal; L, lateral; $M$, medial; $R$, rostral. $C, D$, Quantification of the entire $V 1$ area and the area within it that represents a $50^{\circ}$ space in visual field in wild-type and $B C l-x L^{\text {Emx } 1-C r e}$ mice. Data shown are means $\pm S E M S$ for each group. ${ }^{*} p<0.05,{ }^{* *} p<0.01,{ }^{* * *} p<0.001$.

had a significant reduction in the number of $\mathrm{Cux} 1^{+}$cells in layers II/III and Brn $1^{+}$cells in layers II-IV of the cortex (Fig. 4G-J). Although deeper layer Tbr $1^{+}$neurons also underwent cell death in $B c l-x L^{E m x I-C r e}$ mice (Fig. $4 K, L$ ), cell death was more prominent in the upper layer cortical neurons.

To examine the physiological relevance of loss of Bcl-xL in the brain, we focused on the V1 as a marker for structural and functional organization of the cortex (Fig. 5A). Surprisingly, despite the significant reduction in layers II-IV of the cortex, in vivo imaging of visual responses to a white bar moving in either a horizontal or vertical direction revealed a functional and retino-

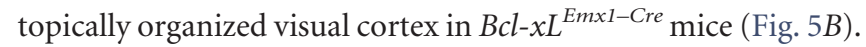
Additional tests using a vertical grating patch found that, although the neurons appeared to be wired in a topographically correct manner, the size of the visual cortex as measured by the whole $\mathrm{V} 1$ area as well as the area representing a $50^{\circ}$ diameter portion of visual space were both significantly smaller in $B c l-x L^{E m x l-C r e}$ mice compared with their wild-type littermates
(Fig. $5 B-D$ ). In fact, as a consequence of the reduced size of the visual cortex, the underlying superior colliculus was fully exposed (Fig. 5A). Thus, we were able to image the retinotopic organization of the superior colliculus within the same field of view that contained the visual cortex in the $B c l-x L^{E m x l-C r e}$ mice (Fig. $5 B$ ). Together, these results highlight the importance of Bcl-xL in maintaining the survival of upper layer neurons, the loss of which led to markedly smaller, yet functional, areas of cortical retinotopy.

\section{Neuronal death induced by $\mathrm{Bcl}-\mathrm{xL}$ deficiency is rescued with codeletion of Bax and Bak}

The key effectors of apoptosis are the proapoptotic proteins Bax and Bak, which can be activated either directly or indirectly by the loss of their binding to the anti-apoptotic proteins such as Bcl-xL (Cheng et al., 2001; Kim et al., 2006; Westphal et al., 2014). Thus, we examined whether the cell death caused by Bcl-xL deficiency is mediated via a Bax- and Bak-dependent apoptotic pathway. To 
A

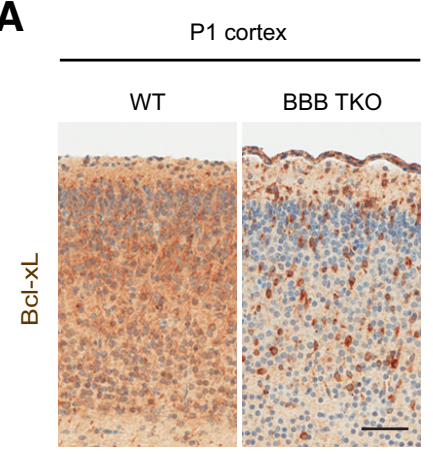

B

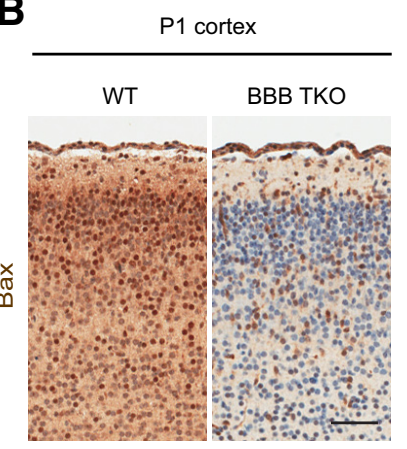

C

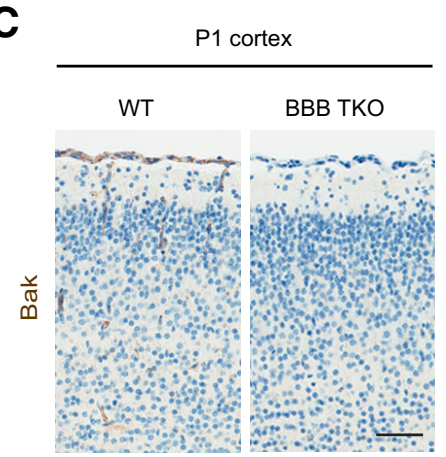

D

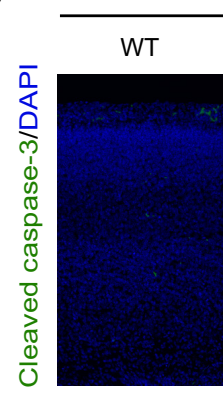

F

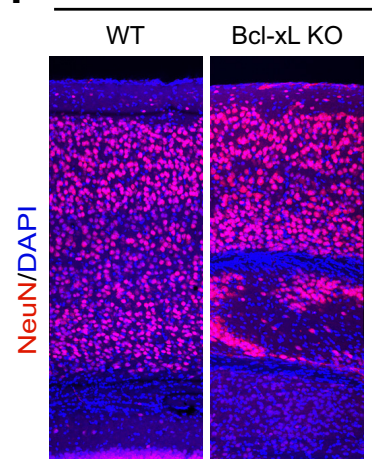

I
$\mathrm{P1}$

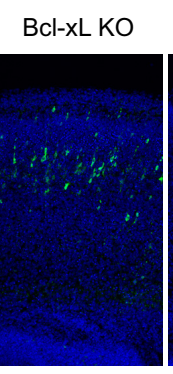

BBB TKO

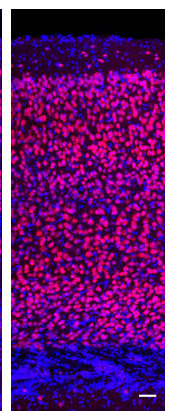

P30

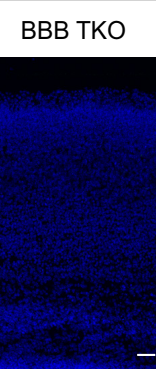

G
E

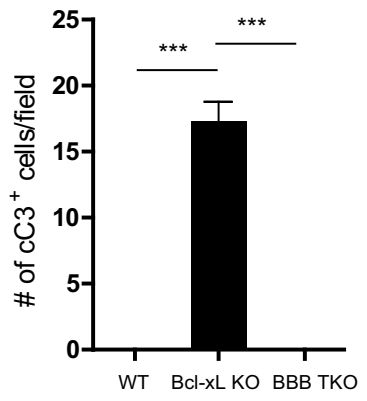

H

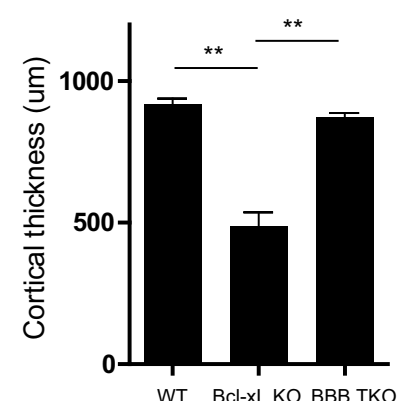

J

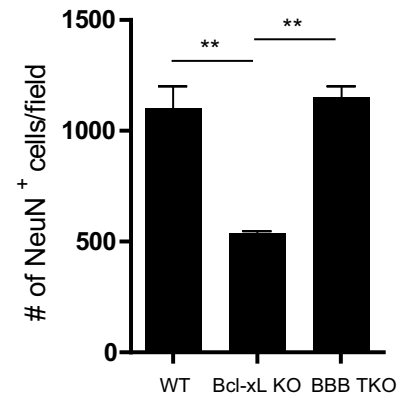

WT BCl-XL KO BBB TKO
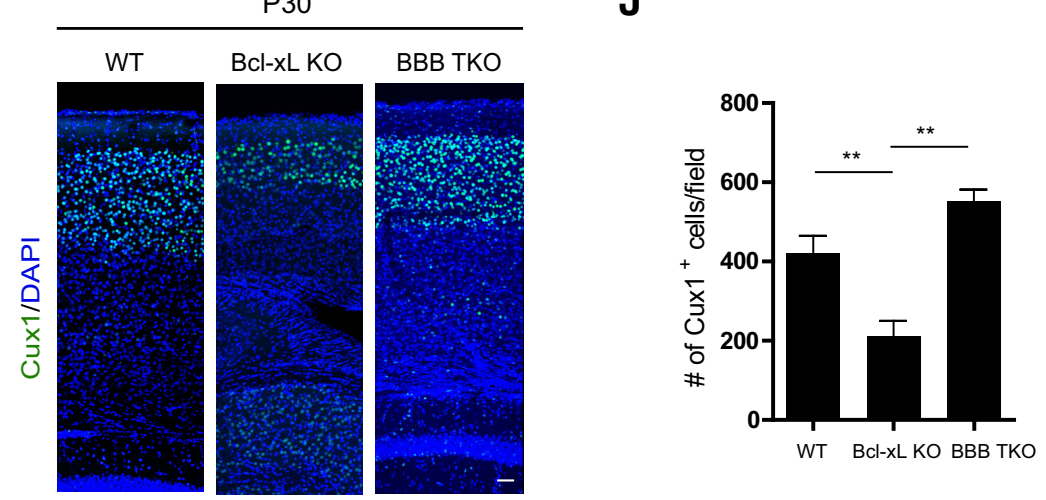

Figure 6. The apoptotic cell death and microcephaly in $B C l-x L^{E m x 1-C r e}$ mice can be rescued with codeletion of Bax and Bak. Cortices of P1 wild-type and BBB TK0 mice stained with $B C l-x L(A)$, Bax (B), Bak (C). Scale bars: $\boldsymbol{A}-\boldsymbol{C}, 50 \mu \mathrm{m}$. D, Cortices from P1 wild-type, $B C l-x L^{\text {Emx1-Cre }}$ (BCl-xL K0), and BBB TK0 mice stained with cleaved caspase-3 and DAPI. Quantification of the number of cleaved caspase-3-positive cells is shown in E.F, Wild-type, Bcl-xL KO, and BBB TKO brains costained with NeuN and DAPI. G, Cortical thickness in P30 wild-type, Bcl-xL K0, and BBB TKO brains. Quantification of the number of NeuN-positive cells is shown in $\boldsymbol{H}$. I, Cortices from P30 wild-type, Bcl-xL K0, and BBB TK0 mice stained with Cux1 and DAPI. J, Quantification of the number of Cux1-positive cells is shown. Data shown are means \pm SEMs for each group. Scale bars: $D, F, I, 50 \mu \mathrm{m} .{ }^{* *} p<0.01,{ }^{* * *} p<0.001$.

test this, we crossed $B c l-x L^{E m x l-C r e}$ mice with $B a x^{\text {loxP/loxP }} ; B a k^{-/-}$ mice to generate $\mathrm{Bax} x^{\text {loxP/loxP }} ; \mathrm{Bcl}-x \mathrm{~L}^{\text {loxP/loxP }} ; \mathrm{Emxl} \mathrm{Cre} ; \mathrm{Bak} \mathrm{k}^{-/-}$triple knock-out mice (triple knock-outs hereafter referred to as BBB TKOs). First, we confirmed that Bcl-xL and Bax underwent recombination in these mice (Fig. 6A,B). Bak, which is known to be minimally expressed in postmitotic neurons in the brain (Krajewski et al., 1996), is globally deleted in the BBB TKO mice (Fig. 6C). BBB TKOs were born at the expected Mendelian ratio and appeared nor- 
A

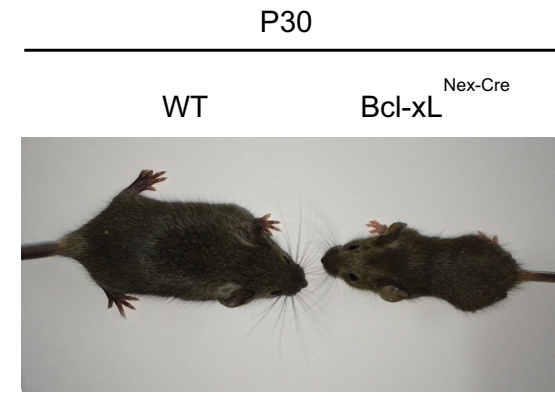

B

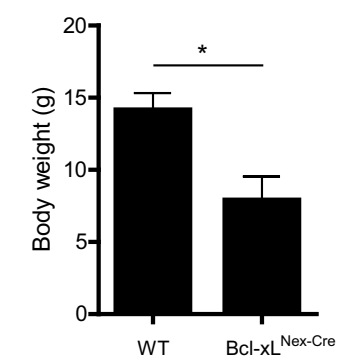

E

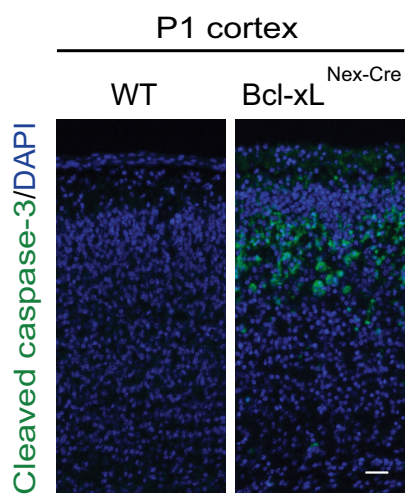

F

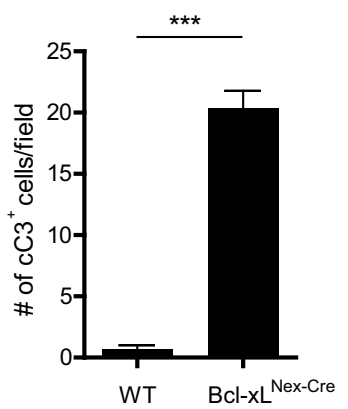

Figure 7. Loss of $B C l-x L$ selectively in postmitotic neurons results in reduced body and brain weights and cell death in the upper regions of the cortex. $A$, Photos of wild-type and $B C l-x L^{\text {Nex-Cre }}$ mice at P30. B, Body weights of wild-type and $B C l-x L^{\text {Nex-Cre }}$ male mice at P30. C, Images of brains isolated from wild-type and $B C 1-x L^{\text {Nex-Cre }}$ mice at P30. D, Brain weights of wild-type and $B C I-x L^{\text {Nex-Cre }}$ male mice at P30. E, Cortices of P1 wild-type and $B C l-x L^{\text {Nex-Cre }}$ mice stained with cleaved caspase-3. $\boldsymbol{F}$, Quantification of the number of cleaved caspase-3-positive cells shown in $E$. Scale bar: $\boldsymbol{E}$, $25 \mu \mathrm{m}$. ${ }^{*} p<0.05,{ }^{* * *} p<0.0001$.

mal at birth (data not shown). More importantly, the apoptotic cell death observed in $B c l-x L^{E m x l-C r e}$ mice was completely rescued in P1 BBB TKO mice (Fig. 6D,E). As a result, the cortical thickness and neuronal numbers at $\mathrm{P} 30$ were completely restored in these triple knock-out mice (Fig. 6F-J). Together, these findings show that the neuronal death observed in the brains of $B c l-x L^{\text {Emxl-Cre }}$ mice can be rescued with deletion of Bax and Bak.

\section{Deletion of Bcl-xL in postmitotic neurons leads to selective neuronal death in the upper layers of the cortex}

Our results show that inducing deletion of Bcl-xL in the NPCs of the dorsal telencephalon leads to the death of mainly postmitotic neurons in the early postnatal animal. To specifically investigate the role of $\mathrm{Bcl}-\mathrm{xL}$ deletion in postmitotic neurons throughout the brain, we used the Nex-Cre mouse model. Nex-Cre directs recombination in the postmitotic neurons at E13.5 and spares recombination in neuronal progenitors (Goebbels et al., 2006). $B c l-x L^{\text {loxP/loxP }} ;$ Nex-Cre mice $\left(B c l-x L^{\text {Nex-Cre }}\right)$, similar to $B c l-x L^{E m x l-C r e}$ mice, were born at the expected Mendelian ratio. Interestingly, $B c l-x L^{N e x-C r e}$ mice displayed smaller body weights at P30 (Fig. $7 A, B$ ). The brains of $B c l-x L^{\text {Nex-Cre }}$ mice were also smaller compared with their wild-type littermate controls (Fig. $7 C, D)$. Importantly, deletion of Bcl-xL in postmitotic neurons in $B c l-x L^{\text {Nex-Cre }}$ mice still resulted in a cell death phenotype in the brain that was similar to what was observed in the $B c l-x L^{\text {Emxl-Cre }}$ mice, with significantly increased cleaved caspase- 3 staining in the upper cortical layers at $\mathrm{P} 1$ (Fig. $7 E, F$ ). Together, our results from both the $B c l-x L^{E m x l-C r e}$ and $B c l-x L^{N e x-C r e}$ mice show that the loss of Bcl-xL does not cause widespread apoptosis in the developing brain but instead results in the loss of postmitotic neurons in the upper regions of the cortex during the early postnatal stages.

Loss of Bcl-xL-dependent neurons results in deficits in motor learning, hyperactivity, and increased risk-taking and selfinjurious behaviors

To determine the functional consequence of $\mathrm{Bcl}-\mathrm{xL}$ deletion in postmitotic neurons, we conducted neurobehavioral assessments of wild-type and $B c l-x L^{\text {Nex-Cre }}$ mice starting at P30. A 3 min tail suspension test revealed that, whereas wild-type mice exhibited the characteristic flailing of their hindlimbs, $B c l-x L^{N e x-C r e}$ mice displayed hindlimb clasping, an indicator of generalized neuro-

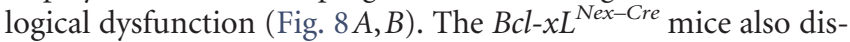
played self-injurious behavior. Persistent skin lesions in their hindlimbs, chest, neck, and other areas began to appear $\sim 1$ month after birth and were observed in $\sim 50 \%$ of these mice (Fig. $8 C$ ). These lesions were not a result of fighting with cage mates, because $\mathrm{Bcl}-x \mathrm{~L}^{\mathrm{Nex}-\mathrm{Cre}}$ mice housed alone also developed these lesions. Analysis of grooming behavior revealed that male $B c l-x L^{\text {Nex-Cre }}$ mice spent significantly more time grooming compared with wild-type controls (Fig. $8 D$ ). Male $B c l-x L^{\text {Nex-Cre }}$ mice also displayed an altered sensation to pain, because they were significantly more insensitive to noxious heat stimuli on the Hargreaves test (Fig. 8E).

In a multitest behavioral regimen, both male and female $B c l-x L^{N e x-C r e}$ mice displayed increased locomotor activity in the open-field test without changes in rearing movements or time spent in the center region (Fig. $9 A-C$ ). Interestingly, male $B c l-x L^{\text {Nex-Cre }}$ mice also displayed significantly increased risktaking behavior because they spent more time in the open arms of 
A

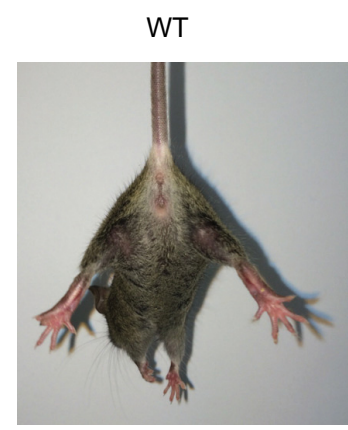

$B c l-\mathrm{xL}^{\text {Nex-Cre }}$

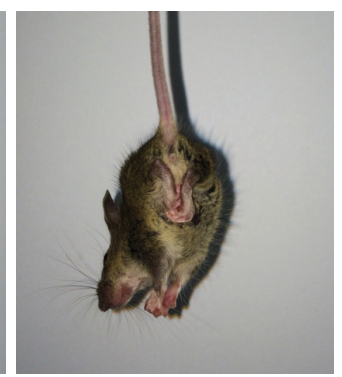

B

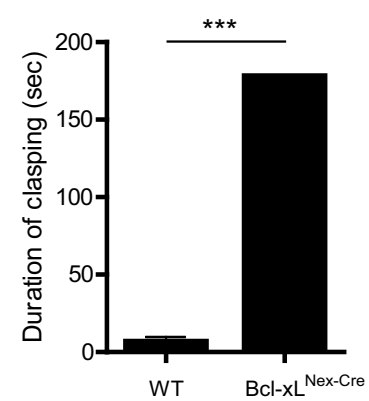

C

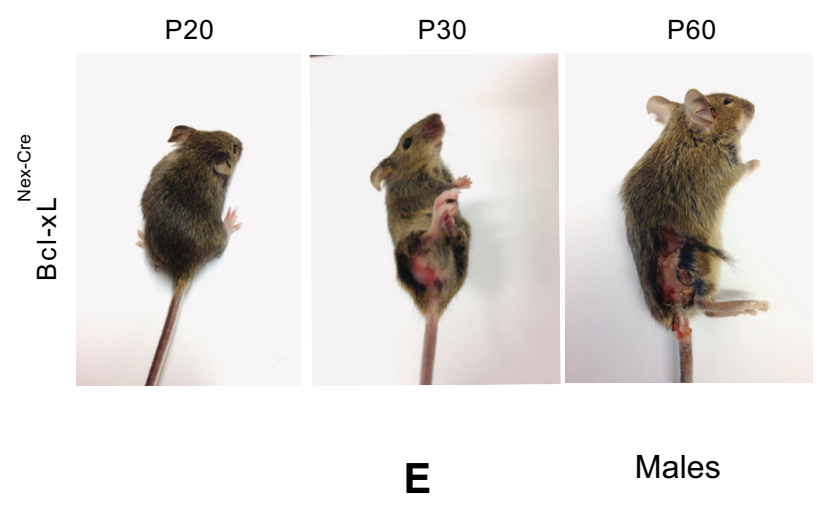

D

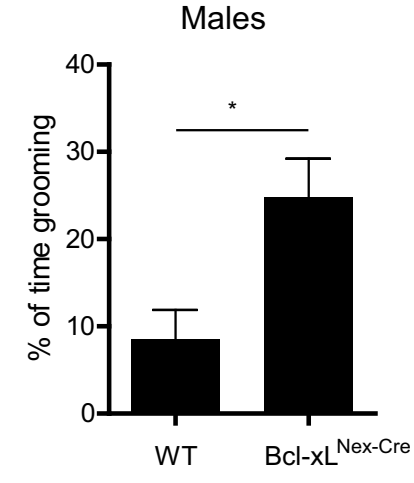

Females
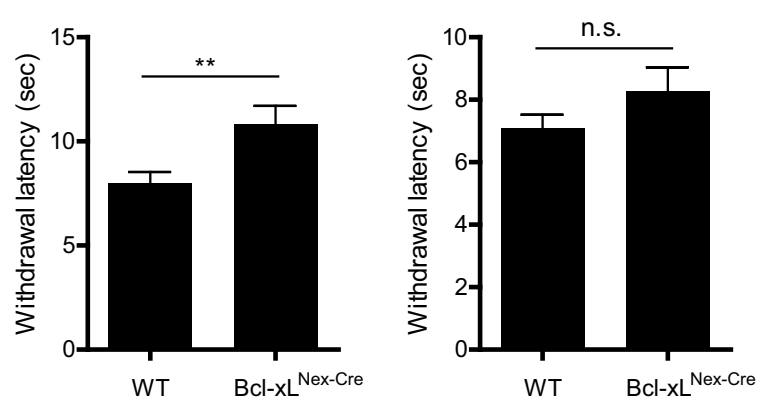

Figure 8. $\quad B C l-x L^{\text {Nex-Cre }}$ mice display self-inflicted skin lesions. $A, B C l-x L^{\text {Nex-Cre }}$ mice spend significantly greater periods of time undergoing hindlimb clasping. Analyses were conducted on $P 30$ wild-type and $B C l-x L^{\text {Nex-Cre }}$ mice. $B$, Quantification of the number of seconds $P 30$ wild-type and $B C l-x L^{\text {Nex-Cre }}$ mice display hindlimb clasping over a 3 min period. Hindlimb clasping was examined in three wild-type and three $B C l-x L^{\text {Nex-Cre }}$ mice. C, Severe skin lesions observed in the hindlimb of $B C l-x L^{\text {Nex-Cre }}$ mice. Lesions began to appear at $\sim 1$ month of age. $D$, Percentage of time spent grooming in wild-type and $B C l-x L^{\text {Nex-Cre }}$ mice. $E$, Withdrawal latency (seconds) in wild-type and $B C l-x L^{\text {Nex-Cre }}$ mice on the Hargreaves apparatus. Data shown are means $\pm S E M s$ for each group. ${ }^{*} p<0.05$, ${ }^{* *} p<0.01,{ }^{* * *} p<0.0001$; n.s., not significant.

the elevated plus maze, suggesting a loss of typical cautionary avoidance of the open areas (Fig. 9D,E). The total number of entries in the elevated plus maze was not altered in the knock-out mice, indicating that the increased risk-taking behavior in the male $B c l-x L^{N e x-C r e}$ mice could not be attributed to general hyperactivity during the test (Fig. $9 F$ ).

In contrast to the intact ability for locomotion and rearing movements, the $B c l-x L^{N e x-C r e}$ knock-out mice had profound deficits in motor coordination on an accelerating rotarod. The $B c l-x L^{\text {Nex-Cre }}$ mice failed to show improvement across repeated trials, indicating impaired motor learning in the rotarod test (Fig. 9G). A subset of Bcl-xL-deficient mice without skin lesions ( 8 of 16) was further evaluated in the Morris water maze task to determine the ability of mice to locate a visible escape platform. Although all of the wild-type mice demonstrated proficient learning in the visible platform test, $B c l-x L^{\text {Nex-Cre }}$ knock-out mice had an overt impairment in reaching the escape platform, with only two $B c l-x L^{N e x-C r e}$ mice meeting the $15 \mathrm{~s}$ criterion for learning across 3 d of testing (Fig. $9 H, I$ ). Together, these results show that $\mathrm{Bcl}-\mathrm{xL}$ plays a critical role in postmitotic neuronal survival and that the Bcl-xL-dependent neurons control a variety of complex behaviors, the loss of which results in severe neurobehavioral abnormalities.

\section{Discussion}

In this study, we show that Bcl-xL is essential for maintaining the survival of specific neurons in the developing mammalian brain. Multiple anti-apoptotic Bcl-2 proteins are expressed at high levels during this period, and they are generally considered to have redundant functions to prevent cell death. However, we demonstrate that the regulation of apoptosis in the developing brain is more nuanced whereby neurons become dependent on Bcl-xL in 
A
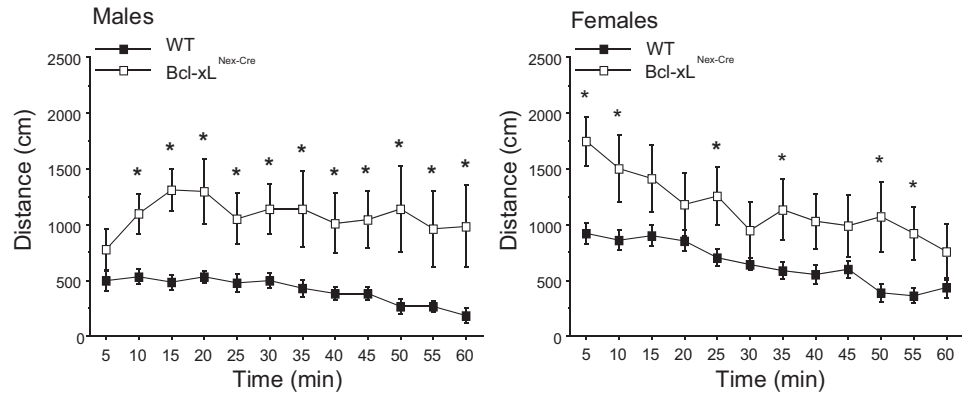

B

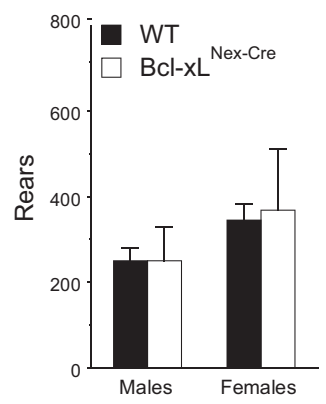

G

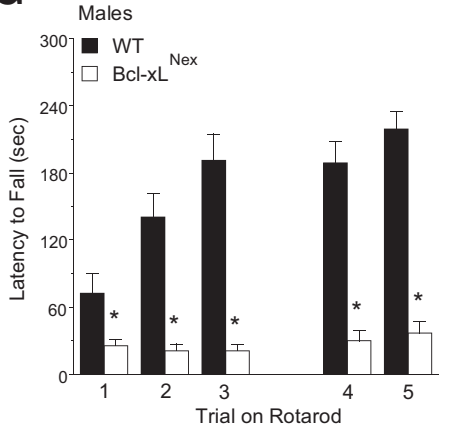

D

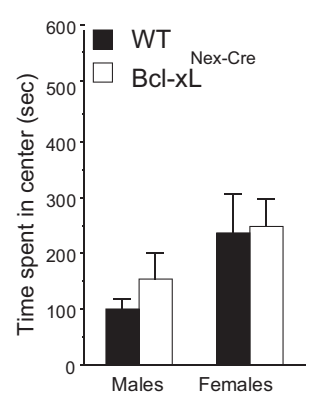

E

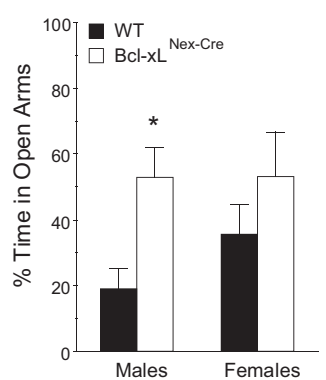

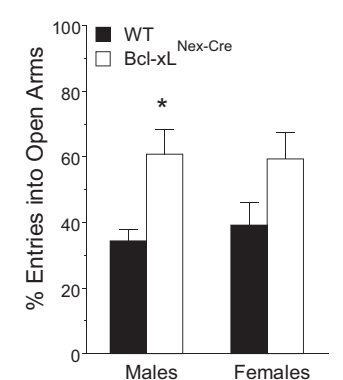

$\mathbf{F}$

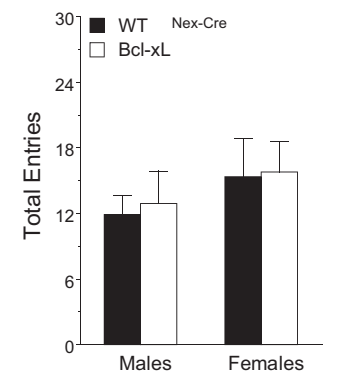

I

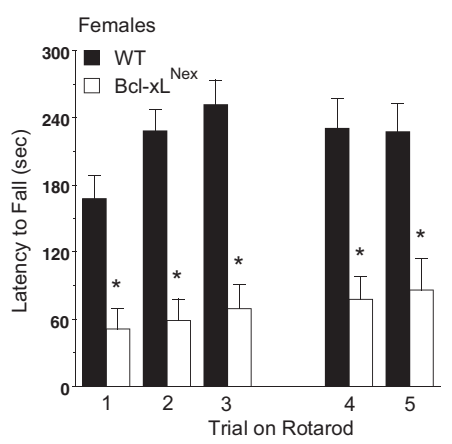

H

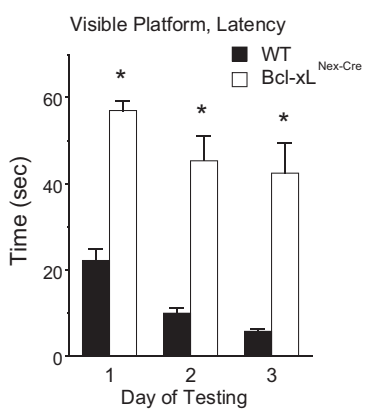

Visible Platform, Speed

${ }^{35}$ - WT

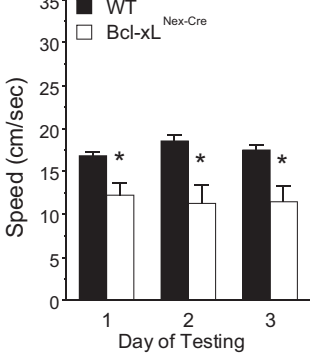

Figure 9. $B C l-x L^{\text {Nex-Cre }}$ mice exhibit numerous neurobehavioral deficits. $A$, Sixty-minute open-field analyses reveal that both male and female $B C l-x L^{\text {Nex-Cre }}$ mice travel significantly greater distances compared with wild-type animals. Both male and female $B C l-x L^{\text {Nex-Cre }}$ mice exhibit similar number of rears $(\boldsymbol{B})$ and spend similar amounts of time in the center of the open field compared with wild-type mice (C).D, Percentage of time spent in the open arms of the elevated plus maze by wild-type and $B C l-x L^{N e x-C r e}$ mice. $\boldsymbol{E}$, Percentage of entries into the open arms of the elevated plus maze by wild-type and $B C l-x L^{N e x-C r e}$ mice. $F$, Total number of entries into the open arms of the elevated plus maze by wild-type and $B C l-x L^{N e x-C r e}$ mice. $G$, Latency to fall from an accelerating rotarod. Latency $(\boldsymbol{H})$ and speed $(\boldsymbol{I})$ in reaching the visible platform in the Morris water maze task in wild-type and $B C l-x L^{\text {Nex-Cre }}$ mice. Data shown are means \pm SEMs for each group. ${ }^{*} p<0.05$.

a specific spatial and temporal context. Loss of Bcl-xL in the rapidly proliferating NPCs does not affect their survival, a finding that is consistent with the observation that $\mathrm{Bcl}-\mathrm{xL}$ is minimally expressed in these cells (Fig. 3 B, C; Motoyama et al., 1995; Roth et al., 2000). However, neurons have high levels of Bcl-xL, and the differentiation of NPCs into neurons increases the susceptibility of these cells to cell death, a phenomenon that can be rescued with codeletion of the proapoptotic proteins Bax and Bak. Importantly, despite the high level of Bcl-xL expression in neurons throughout all layers of the cortex, loss of Bcl-xL did not induce apoptosis in all neurons. Instead, only a subset of neurons, especially those in the upper layers of the cortex, was critically dependent on Bcl-xL.

Conditional deletion of Bcl-xL selectively in the postmitotic neurons led to a similar cell death phenotype and resulted in a variety of neurobehavioral consequences in the animal, including deficits in motor learning, self-inflicted injury, and hyperactivity. These results show that the loss of $\mathrm{Bcl}-\mathrm{xL}$ in the developing brain does not result in widespread apoptosis and neurodegeneration.
Indeed, these mice survive and maintain basic brain functions (e.g., ambulation, breathing, reproduction). Instead, Bcl-xL appears to be most critical to regulate the survival and function of postmitotic neurons during the period of high-level associative connectivity that is essential for the refinement of complex behaviors during mammalian brain development. Interestingly, our results reveal that body weight is also regulated by Bcl-xLdependent neurons. Whether this is a consequence of the loss of $\mathrm{Bcl}$-xL-expressing neurons in the hypothalamus that regulate appetite and feeding behavior remains to be determined.

Embryonic and early postnatal brain development are dynamic processes characterized by rapid proliferation of NPCs, their differentiation into postmitotic neurons, migration of neurons to their final destinations, and establishment of proper synaptic connections. The period of mammalian brain development is also extensively regulated by apoptosis. The importance of physiological cell death is highlighted by the fact that deletion of proapoptotic genes during rapid NPC division leads to hyperproliferation of these cells, resulting in enlarged and abnormal brains 
and embryonic or perinatal lethality (Kuida et al., 1996, 1998; Cecconi et al., 1998; Hakem et al., 1998; Woo et al., 1998; Yoshida et al., 1998). Despite multiple redundancies in the anti-apoptotic $\mathrm{Bcl}-2$ proteins (including $\mathrm{Bcl}-2, \mathrm{Bcl}-\mathrm{xL}, \mathrm{Mcl}-1$, and $\mathrm{Bcl}-\mathrm{w}$ ), deletion of these anti-apoptotic genes also has consequences; however, the phenotypes of mice deficient in each of these antiapoptotic proteins do not overlap. For example, although Bcl-2 is expressed at high levels in the brains of both embryonic and adult mice (Merry et al., 1994; Davies 1995), deletion of Bcl-2 leads to normal embryonic development of the CNS. Only after postnatal development do Bcl-2-deficient mice begin to exhibit abnormalities, including the degeneration of various populations of PNS neurons (Michaelidis et al., 1996) and the appearance of gray hair and polycystic kidney disease (Veis et al., 1993; Nakayama et al., 1994). The expression of Bcl-w, an anti-apoptotic protein involved in axon maintenance, increases during postnatal development and is expressed at high levels in the adult brain. Deletion of $\mathrm{Bcl}-\mathrm{w}$ results in a viable yet smaller animal during the early postnatal stages; although the adult mice appear normal, the male knock-outs are sterile as a result of testicular degeneration (Ross et al., 1998). Mcl-1 has also been shown to be critical for the developing nervous system, whereby this gene is highly expressed in both the rapidly proliferating NPCs as well as in the newly born neurons of the telencephalon. Conditional deletion of Mcl-1 specifically in the neural progenitors of the CNS resulted in embryos with a significantly reduced size in the telencephalon (Arbour et al., 2008) as a result of extensive cell death in the NPCs and immature neurons of the cortical plate.

Bcl-xL-deficient mice are embryonic lethal at E13.5, with prominent cell death in the hematopoietic and nervous systems. Although this early lethality precluded any functional characterization of the Bcl-xL-deficient mice, increased cell death was observed in the neurons of the developing telencephalon of $\mathrm{Bcl}-\mathrm{xL}$-deficient mice. Conditional deletion of $\mathrm{Bcl}-\mathrm{xL}$ in the catecholaminergic neurons also results in increased cell death (Savitt et al., 2005). These results are consistent with the observation that $\mathrm{Bcl}-\mathrm{xL}$ is highly expressed in the intermediate and marginal zones containing postmitotic neurons but is excluded from the rapidly proliferating cells of the ventricular zone (Motoyama et al., 1995; Roth et al., 2000). Interestingly, recent studies have also identified non-apoptotic functions of Bcl-xL in neurons. Specifically, Bcl-xL increases neurite outgrowth (Kretz et al., 2004; Park et al., 2015) and enhances the synaptic activity of postmitotic neurons in the adult brain by regulating mitochondrial membrane conductance (Jonas et al., 2003; Li et al., 2008, 2013). Thus, the increased neuronal death seen with Bcl-xL deficiency could either be a direct consequence of $\mathrm{Bcl}-\mathrm{xL}$ deletion leading to apoptosis or an indirect consequence of $\mathrm{Bcl}-\mathrm{xL}$ loss causing neuronal dysfunction via the inability of neurons to promote neurite outgrowth and maintain synaptic activity.

Importantly, although the conditional deletion of $\mathrm{Bcl}-\mathrm{xL}$ with Emx1-Cre induces recombination in neural progenitors of the telencephalon (Gorski et al., 2002), our finding that upper layer cortical neurons are more susceptible to undergoing cell death with loss of $\mathrm{Bcl}-\mathrm{xL}$ suggests that there is selectivity in triggering cell death among cortical neurons. The upper layer cortical neurons are known to be expanded during primate evolution, and defects in their function are associated with psychiatric disorders, such as autism spectrum disorders (Fang et al., 2014). Interestingly, many of the behavioral deficits, including measures for anxiety-like behavior with the elevated plus maze and rotarod, were more severe in male $\mathrm{Bcl}-x L^{\mathrm{Nex}-\mathrm{Cre}}$ mice compared with the females. Overall, our results, which show that the loss of these neurons leads to neurobehavioral deficits with gender differences, point to the critical importance of Bcl-xL-dependent neurons in the establishment of complex behaviors.

\section{References}

Arbour N, Vanderluit JL, Le Grand JN, Jahani-Asl A, Ruzhynsky VA, Cheung EC, Kelly MA, MacKenzie AE, Park DS, Opferman JT, Slack RS (2008) Mcl-1 is a key regulator of apoptosis during CNS development and after DNA damage. J Neurosci 28:6068-6078. CrossRef Medline

Besirli CG, Deckwerth TL, Crowder RJ, Freeman RS, Johnson EM Jr 2003 Cytosine arabinoside rapidly activates Bax-dependent apoptosis and a delayed Bax-independent death pathway in sympathetic neurons. Cell Death Differ 10:1045-1058. Medline

Brainard DH (1997) The Psychophysics Toolbox. Spat Vis 10:433-436. CrossRef Medline

Cecconi F, Alvarez-Bolado G, Meyer BI, Roth KA, Gruss P (1998) Apaf1 (CED-4 homolog) regulates programmed cell death in mammalian development. Cell 94:727-737. CrossRef Medline

Chen YB, Aon MA, Hsu YT, Soane L, Teng X, McCaffery JM, Cheng WC, Qi B, Li H, Alavian KN, Dayhoff-Brannigan M, Zou S, Pineda FJ, O'Rourke B, Ko YH, Pedersen PL, Kaczmarek LK, Jonas EA, Hardwick JM (2011) Bcl-xL regulates mitochondrial energetics by stabilizing the inner membrane potential. J Cell Biol 195:263-276. CrossRef Medline

Cheng EH, Wei MC, Weiler S, Flavell RA, Mak TW, Lindsten T, Korsmeyer SJ (2001) BCL-2, BCL-XL sequester BH3 domain-only molecules preventing BAX- and BAK-mediated mitochondrial apoptosis. Mol Cell 8: 705-711. CrossRef Medline

Chipuk JE, Moldoveanu T, Llambi F, Parsons MJ, Green DR (2010) The BCL-2 family reunion. Mol Cell 37:299-310. CrossRef Medline

Davies AM (1995) The Bcl-2 family of proteins, and the regulation of neuronal survival. Trends Neurosci 18:355-358. CrossRef Medline

Deckwerth TL, Elliott JL, Knudson CM, Johnson EM Jr, Snider WD, Korsmeyer SJ (1996) Bax is required for neuronal death after trophic factor deprivation and during development. Neuron 17:401-411. CrossRef Medline

Dekkers MP, Barde YA (2013) Programmed cell death in neuronal development. Science 340:39-41. CrossRef Medline

Dekkers MP, Nikoletopoulou V, Barde YA (2013) Death of developing neurons: new insights and implications for connectivity. J Cell Biol 203: 385-393. CrossRef Medline

Fang WQ, Chen WW, Jiang L, Liu K, Yung WH, Fu AK, Ip NY (2014) Overproduction of upper-layer neurons in the neocortex leads to autismlike features in mice. Cell Rep 9:1635-1643. CrossRef Medline

Goebbels S, Bormuth I, Bode U, Hermanson O, Schwab MH, Nave KA (2006) Genetic targeting of principal neurons in neocortex and hippocampus of NEX-Cre mice. Genesis 44:611-621. CrossRef Medline

González-García M, Pérez-Ballestero R, Ding L, Duan L, Boise LH, Thompson CB, Núñez G (1994) bcl-XL is the major bcl-x mRNA form expressed during murine development and its product localizes to mitochondria. Development 120: 3033-3042. Medline

González-García M, García I, Ding L, O’Shea S, Boise LH, Thompson CB, Núñez G (1995) bcl-x is expressed in embryonic and postnatal neural tissues and functions to prevent neuronal cell death. Proc Natl Acad Sci U S A 92:4304-4308. CrossRef Medline

Gorski JA, Talley T, Qiu M, Puelles L, Rubenstein JL, Jones KR (2002) Cortical excitatory neurons and glia, but not GABAergic neurons, are produced in the Emx1-expressing lineage. J Neurosci 22:6309-6314. Medline

Hakem R, Hakem A, Duncan GS, Henderson JT, Woo M, Soengas MS, Elia A, de la Pompa JL, Kagi D, Khoo W, Potter J, Yoshida R, Kaufman SA, Lowe SW, Penninger JM, Mak TW (1998) Differential requirement for caspase 9 in apoptotic pathways in vivo. Cell 94:339-352. CrossRef Medline

Jonas EA, Hoit D, Hickman JA, Brandt TA, Polster BM, Fannjiang Y, McCarthy E, Montanez MK, Hardwick JM, Kaczmarek LK (2003) Modulation of synaptic transmission by the BCL-2 family protein BCL-xL. J Neurosci 23:8423-8431. Medline

Kalatsky VA, Stryker MP (2003) New paradigm for optical imaging: temporally encoded maps of intrinsic signal. Neuron 38:529-545. CrossRef Medline

Kim H, Rafiuddin-Shah M, Tu HC, Jeffers JR, Zambetti GP, Hsieh JJ, Cheng EH (2006) Hierarchical regulation of mitochondrion-dependent apo- 
ptosis by BCL-2 subfamilies. Nat Cell Biol 8:1348-1358. CrossRef Medline

Krajewski S, Krajewska M, Reed JC (1996) Immunohistochemical analysis of in vivo patterns of Bak expression, a proapoptotic member of the Bcl-2 protein family. Cancer Res 56:2849-2855. Medline

Kretz A, Kügler S, Happold C, Bähr M, Isenmann S (2004) Excess Bcl-XL increases the intrinsic growth potential of adult CNS neurons in vitro. Mol Cell Neurosci 26:63-74. CrossRef Medline

Kuida K, Zheng TS, Na S, Kuan C, Yang D, Karasuyama H, Rakic P, Flavell RA (1996) Decreased apoptosis in the brain and premature lethality in CPP32-deficient mice. Nature 384:368-372. CrossRef Medline

Kuida K, Haydar TF, Kuan CY, Gu Y, Taya C, Karasuyama H, Su MS, Rakic P, Flavell RA (1998) Reduced apoptosis and cytochrome c-mediated caspase activation in mice lacking caspase 9. Cell 94:325-337. CrossRef Medline

Li H, Chen Y, Jones AF, Sanger RH, Collis LP, Flannery R, McNay EC, Yu T, Schwarzenbacher R, Bossy B, Bossy-Wetzel E, Bennett MV, Pypaert M, Hickman JA, Smith PJ, Hardwick JM, Jonas EA (2008) Bcl-xL induces Drp1-dependent synapse formation in cultured hippocampal neurons. Proc Natl Acad Sci U S A 105:2169-2174. CrossRef Medline

Li H, Alavian KN, Lazrove E, Mehta N, Jones A, Zhang P, Licznerski P, Graham M, Uo T, Guo J, Rahner C, Duman RS, Morrison RS, Jonas EA (2013) A Bcl-xL-Drp1 complex regulates synaptic vesicle membrane dynamics during endocytosis. Nat Cell Biol 15:773-785. CrossRef Medline

Merry DE, Veis DJ, Hickey WF, Korsmeyer SJ (1994) bcl-2 protein expression is widespread in the developing nervous system and retained in the adult PNS. Development 120:301-311. Medline

Michaelidis TM, Sendtner M, Cooper JD, Airaksinen MS, Holtmann B, Meyer M, Thoenen H (1996) Inactivation of bcl-2 results in progressive degeneration of motoneurons, sympathetic and sensory neurons during early postnatal development. Neuron 17:75-89. CrossRef Medline

Motoyama N, Wang F, Roth KA, Sawa H, Nakayama K, Nakayama K, Negishi I, Senju S, Zhang Q, Fujii S, Loh DY (1995) Massive cell death of immature hematopoietic cells and neurons in Bcl-x-deficient mice. Science 267:1506-1510. CrossRef Medline

Nakayama K, Nakayama K, Negishi I, Kuida K, Sawa H, Loh DY (1994) Targeted disruption of Bcl-2 alpha beta in mice: occurrence of gray hair, polycystic kidney disease, and lymphocytopenia. Proc Natl Acad Sci U S A 91:3700-3704. CrossRef Medline

Oppenheim RW (1991) Cell death during development of the nervous system. Annu Rev Neurosci 14:453-501. CrossRef Medline

Park HA, Licznerski P, Alavian KN, Shanabrough M, Jonas EA (2015) $\mathrm{Bcl}-\mathrm{xL}$ is necessary for neurite outgrowth in hippocampal neurons. Antioxid Redox Signal 22:93-108. CrossRef Medline

Pelli DG (1997) The VideoToolbox software for visual psychophysics: transforming numbers into movies. Spat Vis 10:437-442. CrossRef Medline
Raff MC, Barres BA, Burne JF, Coles HS, Ishizaki Y, Jacobson MD (1993) Programmed cell death and the control of cell survival: lessons from the nervous system. Science 262:695-700. CrossRef Medline

Rinkenberger JL, Horning S, Klocke B, Roth K, Korsmeyer SJ (2000) Mcl-1 deficiency results in peri-implantation embryonic lethality. Genes Dev 14:23-27. Medline

Ross AJ, Waymire KG, Moss JE, Parlow AF, Skinner MK, Russell LD, MacGregor GR (1998) Testicular degeneration in Bclw-deficient mice. Nat Genet 18:251-256. CrossRef Medline

Roth KA, Kuan C, Haydar TF, D’Sa-Eipper C, Shindler KS, Zheng TS, Kuida K, Flavell RA, Rakic P (2000) Epistatic and independent functions of Caspase- 3 and $\mathrm{Bcl}-\mathrm{X}(\mathrm{L})$ in developmental programmed cell death. Proc Natl Acad Sci U S A 97:466-471. CrossRef Medline

Roth KA, Motoyama N, Loh DY (1996) Apoptosis of bcl-x-deficient telencephalic cells in vitro. J Neurosci 16:1753-1758. Medline

Savitt JM, Jang SS, Mu W, Dawson VL, Dawson TM (2005) Bcl-x is required for proper development of the mouse substantia nigra. J Neurosci 25: 6721-6728. CrossRef Medline

Schindelin J, Arganda-Carreras I, Frise E, Kaynig V, Longair M, Pietzsch T, Preibisch S, Rueden C, Saalfeld S, Schmid B, Tinevez JY, White DJ, Hartenstein V, Eliceiri K, Tomancak P, Cardona A (2012) Fiji: an opensource platform for biological-image analysis. Nat Methods 9:676-682. CrossRef Medline

Smith SL, Trachtenberg JT (2007) Experience-dependent binocular competition in the visual cortex begins at eye opening. Nat Neurosci 10: 370-375. CrossRef Medline

Vander Heiden MG, Li XX, Gottleib E, Hill RB, Thompson CB, Colombini M (2001) Bcl-xl promotes the open configuration of the voltage-dependent anion channel and metabolite passage through the outer mitochondrial membrane. J Biol Chem 276:19414-19419. CrossRef Medline

Veis DJ, Sorenson CM, Shutter JR, Korsmeyer SJ (1993) Bcl-2-deficient mice demonstrate fulminant lymphoid apoptosis, polycystic kidneys, and hypopigmented hair. Cell 75:229-240. CrossRef Medline

Westphal D, Kluck RM, Dewson G (2014) Building blocks of the apoptotic pore: how Bax and Bak are activated and oligomerize during apoptosis. Cell Death Differ 21:196-205. CrossRef Medline

Woo M, Hakem R, Soengas MS, Duncan GS, Shahinian A, Kägi D, Hakem A, McCurrach M, Khoo W, Kaufman SA, Senaldi G, Howard T, Lowe SW, Mak TW (1998) Essential contribution of caspase 3/CPP32 to apoptosis and its associated nuclear changes. Genes Dev 12:806-819. CrossRef Medline

Yoshida H, Kong YY, Yoshida R, Elia AJ, Hakem A, Hakem R, Penninger JM, Mak TW (1998) Apaf1 is required for mitochondrial pathways of apoptosis and brain development. Cell 94:739-750. CrossRef Medline

Youle RJ, Strasser A (2008) The BCL-2 protein family: opposing activities that mediate cell death. Nat Rev Mol Cell Biol 9:47-59. CrossRef Medline 